\title{
THE TIMIŞ RIVER BASIN (BANAT, ROMANIA) NATURAL AND ANTHROPOGENIC ELEMENTS. A STUDY CASE - MANAGEMENT CHALENGES
}

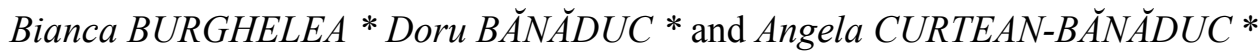 \\ * "Lucian Blaga" University of Sibiu, Faculty of Sciences, Department of Ecology and Environment \\ Protection, Dr. Raţiu Street 5-7, Sibiu, Sibiu County, Romania, RO-550012, \\ burghelea.bianca@yahoo.com, ad.banaduc@yahoo.com, angela.banaduc@ulbsibiu.ro
}

DOI: 10.2478/trser-2013-0041

KEYWORDS: Timiş River, natural background, anthropogenic impacts, management needs.

\section{ABSTRACT}

This study presents a summary of the human impact activity analysis that has influenced the ecological state of the Timiş River.

The results show that because of human activity the Timiş riverbed has been significantly changed due to serious degradation of water quality and extinction of aquatic biota.

In the context of the European Water Framework Directive, in order to achieve water quality standards, the present work aims to take stock of the main human intervention and its effects within the basin to find adequate management solutions to achieve "good ecologically status".

RE்SUME: Les éléments naturels et anthropogéniques du bassin de la rivière Timiş (Banat, Roumanie). Une étude de cas - La mise à l'épreuve d'une gestion.

Cet article présente une synthèse de l'analyse des activités humaines d'impact ont influencé l'état écologique de la rivière Timiş.

Les résultats montrent que le lit de la rivière Timiş, car de nombreuses activités humaines réalisées, il ya eu des changements mineurs dans le lit de la rivière, une grave dégradation de la qualité de l'eau et l'élimination des organismes aquatiques.

Afin d'atteindre les normes de qualité de l'eau dans le contexte de la directive cadre européenne sur l'eau, ce document vise à faire le point de la principale intervention humaine dans le bassin et les changements qu'ils amenés à des solutions de gestion appropriées pour atteindre un "bon état de vue écologique".

REZUMAT: Elemente naturale şi antropice ale bazinul râului Timiş (Banat, România). Studiu de caz - provocări de management.

Lucrarea de față prezintă o sinteză a analizei privind impactul activităților umane ce au influențat starea ecologică a râului Timiș.

Rezultatele arată că la nivelul albiei râului Timiş, datorită numeroaselor activităţi umane desfăsurate, s-au produs modificări ale albiei minore a râului, degradarea gravă a calității apei şi eliminarea elementelor de biota acvatică.

În vederea atingerii standardelor de calitate a apei în contextul Directivei Europene Cadru pentru Apă, lucrarea de față își propune realizarea unui bilanț a principalelor intervenții antropice din cadrul bazinului și a modificărilor induse de acestea pentru a găsi soluții de management adecvate pentru atingerea unei „stări bune din punct de vedere ecologic”. 


\section{INTRODUCTION}

Since water is indispensable to human life, the human history cannot be understood if its relation to the rivers, lakes and underground water is not understood. The humans lived along the rivers and near the lakes or wetlands since the beginning of their history. Great ancient civilizations (Egypt, Mesopotamia, China, etc.) relied obviously on important water sources (Nile, Tigris, Euphrates, Yellow, Yangzi, etc.). The river waters have been and will be a direct source of food for humans, facilitate explorations, transport and agricultural use of the riverine lands, satisfy the communities' hygiene needs, provide an energy source or space for relaxation. (Goubert, 1989; Fagan, 2011; Solomon, 2010; Diamond, 2011; Laenen and Dunnette, 1997; Alcamo et al., 2007; Postel, 2000) Tiny villages or the world's great cities usually need the proximity of rivers or lakes. Different studies revealed the economic value of river basins in the billions of dollars (Schuyt, 2005). In the man-river relation, many types of coexistence can be seen, based on the humans' attitude and actions. At one end, the improvement efforts for water supply and waste management in France, in the 19th century, exemplify humanity's desire for using water to increase the life standards. At another end the efforts of Russia to create canals and dams in the 1930s show the follies humans can do in their illusions to control water. In general people once thought that the associated natural resources and services offered by rivers were endless but now we understand the opposite bitter truth at a global scale. (Pandi, 2002; Henrichs and Alcamo, 2001; Hughes, 1978; Van Dijk et al., 1994; Malmqvist and Rundle, 2002; Allan, 2004; Lacoste, 2003; Turner et al., 2007)

The Europeans need and love their rivers but they also abuse them. Even the large ones such asVolga, Danube, Rhine and Rhône can no longer be assured of reaching the sea unhindered. In Europe this situation is more complex due to the presence of over 150 transborder rivers. Danube is a complex river itself due to the fact that this 29th largest river in the world passes through 19 countries and 10 ecoregions. (Tockner et al., 2009; Müller, 1995; Litvinov et al., 2009).

As far as aquatic and semiaquatic species goes, Danube is the richest basin in Europe. About $20 \%$ of European freshwater fish fauna, representing 115 native species, occur in this basin. Danube's ecological status and fishing activity are influenced by regularization schemes which began in the 19th century and early 20th century. In total, approximately 600 major hydraulic plant structures (dams and weirs greater than $15 \mathrm{~m}$ ), including hydroelectric dams (over 160) were built along the Danube and its main tributaries; this does not include many smaller dams. Over the main course of the Danube River, 69 dams have been built and $30 \%$ of its total length is occupied. Upstream of Bratislava City, only about $15 \%$ of the $1000 \mathrm{~km}$ remain free. Furthermore, there are 34 dams along the river Lech, Austria/Germany. Instead, the river Isar is one of the last natural alpine rivers in Europe. Construction of damsystems on river Gabcikovo near Bratislava, opened in 1992, led to a decline in annual fish catch by more than $80 \%$ in 1993, compared to the pre-dam period (1961-1979). Construction of the hydroelectric plant Iron Gates $(1972,1984)$ had a major impact on the sturgeon populations in the middle of the Danube. The major consequences of the regularization of the Danube River, including its tributaries, are flood reduction (Inn - 210 ha of the 1600 ha existing in 1855, Moravia and Siret), loss of fish and invertebrate stocks (Drava), increased soil salinity (Tisza/Tisa), clogging the downstream hydraulic works (clogging of lake Brăteşti due to hydropower plant Stânca-Costeşti situated on the river Prut) (Sommerwerk et al., 2009).

Agriculture and forestry were the first human activities which determined major changes in management discharge and sediment transport. After the XI century, river actions were elementary and relied moustly on dam construction for flood control and ground recovery 
(Tockner et al., 2009). In the last century mechanization has highly increased productivity. This high increase determined environmental problems such as the desertification, erosion, salinisation, compaction and pollution of the soil. The use of chemical fertilizers has led to an accumulation of nitrates and phosphates in soils and their leakage into rivers and lakes. If the leakage occurred, some processes such as eutrophication and the death of ichthyofauna appeared (O'Connor, 2005). Despite their undeniable advantages (rich crops, the eradication or the supervision of some diseases transmitted by some insects - malaria, trypanosomiasis, filariasis, etc.) the widespread use of these compounds has led to unexpected and very serious side effects such as mass mortality of organisms, mutations and cancer diseases in humans and animals, reduction of primary production process and, not the least, the appearance of induced tolerance (Barbu, 2010).

Agricultural development in floodplains along with the river regularization for navigation and land protection led to the loss of wetlands (about $50 \%$ ) and floodplains (above $95 \%$ ). In 45 European countries, over $80 \%$ of floodplain forests have disappeared. From the former floodplain area of $26,000 \mathrm{~km}^{2}$ along the Danube and its major tributaries, approximately $20,000 \mathrm{~km}^{2}$ were lost. Switzerland lost about $95 \%$ of the original floodplain over the last two centuries (Tockner et al., 2009).

At present, European rivers have problems with the substances derived from agriculture. The damming of banks and the conversion of wetlands into agricultural lands in the Danube Basin affect reproduction areas for some species of migratory fish and birds. For example, the quantity of sturgeon and carp decreased by $98 \%$ and $90 \%$ (Vădineanu et al., 2001). In the Romanian part of the Danube the major changes began between 1960-1989, when $1000 \mathrm{~km}^{2}$ of polders were used for agriculture and fish breeding (Sommerwerk et al., 2009).

The cities are permanent sources of water pollution and the wastewater is continuously produced by diverse human activities. In industrialized areas in Europe wastewater discharge in rivers and lakes led to serious degradation of water quality and extinction of aquatic biota. Past dumping practices led to soil and stream and groundwater pollution by a variety of chemical and biological contaminants, including organic compounds and pathogens (O’Connor, 2005).

Currently, over $70 \%$ of the European population lives in urban areas; the number of cities with a population greater than 100000 inhabitants is about 350 (Tockner et al., 2009). According to the EU Water Framework Directive, 60\% of European cities exploit their groundwater resources irrationally and three quarters of Europeans are supplying with water from underground sources in the depths of the Earth.

Danube River drains 19 countries with a total of 83 million people. Approximately 6\% of the total population in the basin is living in areas below the flood level. From 1950 to 1970 water quality has been affected primarily in urban and industrial areas in the upper Danube. In addition, the ability of self-purification of the inputs suffered because of toxic industrial wastewaters.

In the early 1980s construction of wastewater treatment plants has led to a major reduction of biodegradable organic matter and improved water quality in the upper Danube River. Today, the main course of the Danube has a relatively good water quality (class II, IIIII). Excessive organic pollution can still be observed on some tributaries in Romania and Bulgaria, the Iskar River, Prut River and Olt River (Sommerwerk et al., 2009). 
Industrial development puts more exploitative pressures on rivers, which presents a risk to human health. Rapid industrial development and inadequate pollution control, between 1950-1970, were the causes for the water quality deterioration in the Danube Basin. Today, the main course of the river Danube has relatively good water quality (Class II, II-III) (Sommerwerk et al., 2009).

The pressure from diverse human activities induced important changes in numerous lotic habitats, biocoenosis and ecosystems structure in the Romanian national territory too. The majority of the taxonomic groups were negatively affected by this human impact. (Sîrbu et al., 1999; Angela Curtean-Bănăduc, 2005; Angela Curtean-Bănăduc et al., 2005, 2009, 2011)

Facing the common pressures and threats (deforestation, riverine lands cultivation, river works and regulation, dredging, draining, fragmentation, pollution, etc.) ten Danubian countries and the European Union ratified the Danube River Protection Convention to found the International Commission for the Protection of the Danube River (ICPDR, 2006). The Danube River Protection Convention decided to apply the European Union Water Framework Directive. However much progress is still to be done in this respect. In 2004 the European Commission's General Director for Environment took charge of the International Commission for the Protection of the Danube River to bring forth a Danube Basin study, to provide a basin overview of lotic systems environmental state (ICPDR, 2004). This overview clearly emphasised the need to concentrate efforts with regard to riparian areas restoration, water quality improvement, flood management improvement, biodiversity conservation, sustainable livelihoods development for riverine human communities, etc., at least in the large and medium sized Danube Watershed component basins. This objective's implementation was rather slow, due to the fact that on many Danube tributaries basins the level of environmental knowledge still needs to be improved.

Usually the Romanians believe that their country is a rich country rather than a poor one with regard to lotic systems related products and services, and the ecological state of the rivers is rather a good one, but the late climate changes evidence and mostly the wrong/insufficient watersheds management should raise interest in studies with results that should reflect the reality and to offer solutions for the improving of the actual situation. These studies should target also the identification of the major environmental problems due to human activities at basins level, the effects prognosis and the proposal of management solutions. The necessity of this study came also from the European Water Framework Directive obligations which should be fulfilled by Romania.

This study intends to offer such needed specific data for the Timiş River basin and to propose some general and specific management topics.

\section{RESULTS AND DISCUSSION}

\section{Natural elements in Timiş River basin}

The Timiş River basin belong to the Danube River watershed and drains $7319 \mathrm{~km}^{2}$, of which $5795 \mathrm{~km}^{2}$ on the Romanian national territory as part of the Banat basin (Fig. 1), is a large and complex basin, its catchment area overlapping on distinct and variable relief units: mountains, hills and plains. (NIMH, 1971; Antonescu et al., 1981) 
In the relief units, the Timiş River catchment area crosses in the upper flow the Semenic Mountains and the Timiş-Cerna tectonic corridor until downstream of Caransebeş locality, while in the middle flow it crosses the hills of Northeast Lugoj locality, the hills of Pogăniş South of Lugoj, and finally the Plain of Banat, forming subdivisions of it (Ujvári, 1972). This river lower sector crosses the Serbian territory.

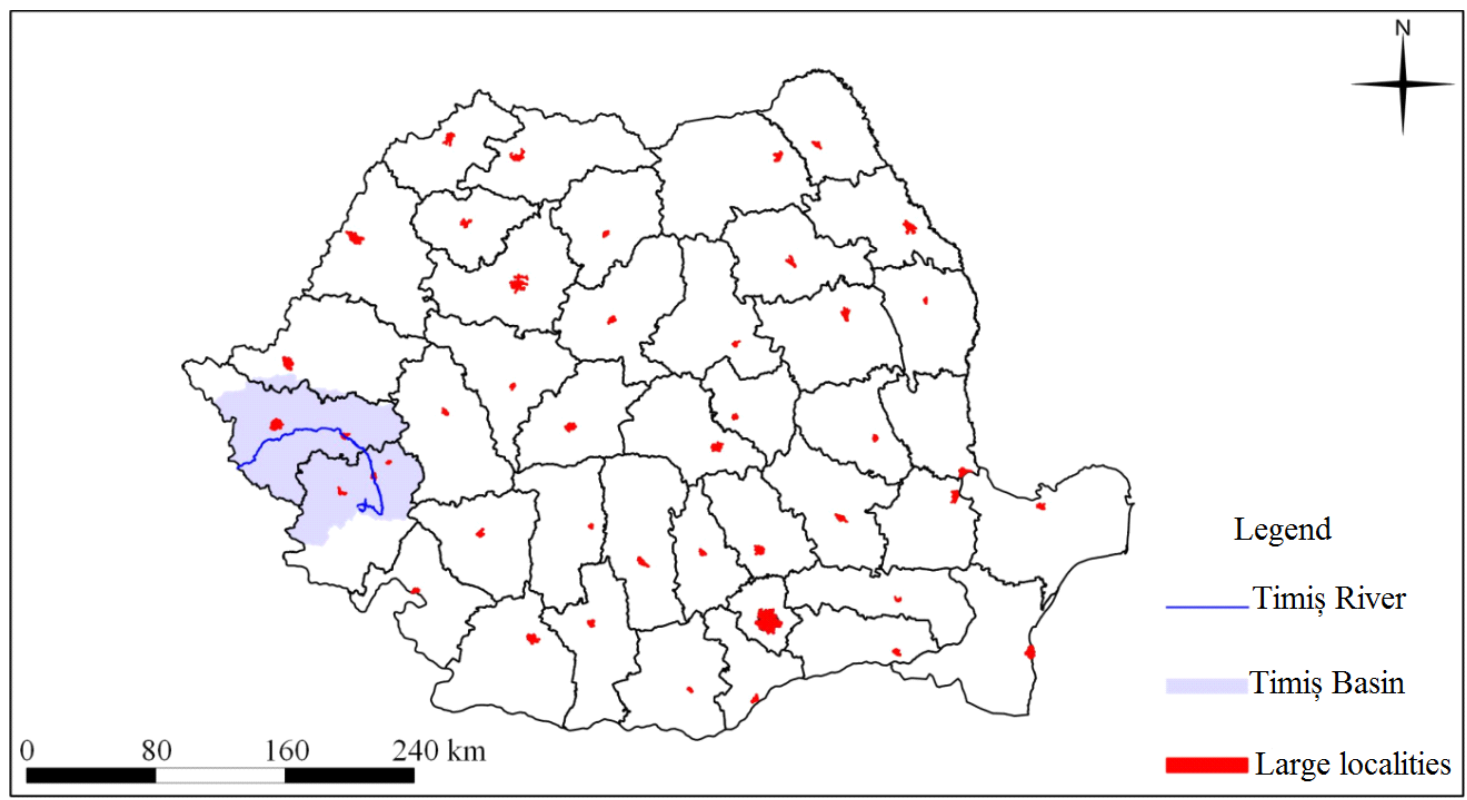

Figure 1: The Timiş River catchment area.

The current physiognomy of the region is the result of long geological (Fig. 2) processes. The area of the Banat Mountains has a relatively common evolution with the Southern Carpathians, but resulted from the collision of Moesian microplate (its Western front) with the Pannonian microplate. In their case, the compression was much smaller than in South and, consequently, the area is less elevated than the Southern Carpathians (Posea, 2002). The Banat Mountains are composed of two main geotectonic units: the indigenous Danube, as one of the oldest nucleus of the Carpathian crystalline, and the Gaetic crystalline consisting of two crystalline series: the Mesocatazonal Semenic suite and the Epizonal suite of Locva-Poiana Ruscă (Antonescu et al., 1981).

The piedmont and the lowland areas were formed at the same time as the Pannonian basin. The Pannonian basin was formed by sinking (starting with Tortonian), at different depths, of an area of the Carpathian crystalline. Over these crystalline blocks were laid sedimentary formations during Tortonian (sand, clay, limestone, sandstone), Sarmatian (marl, sand, sandy marl, lignite intercalations), Pannonian (marl, clay, sand, gravel), and Quaternary deposits (gravel, sand, clay, red clay, loess) covered the field (Munteanu and Munteanu, 1998). 


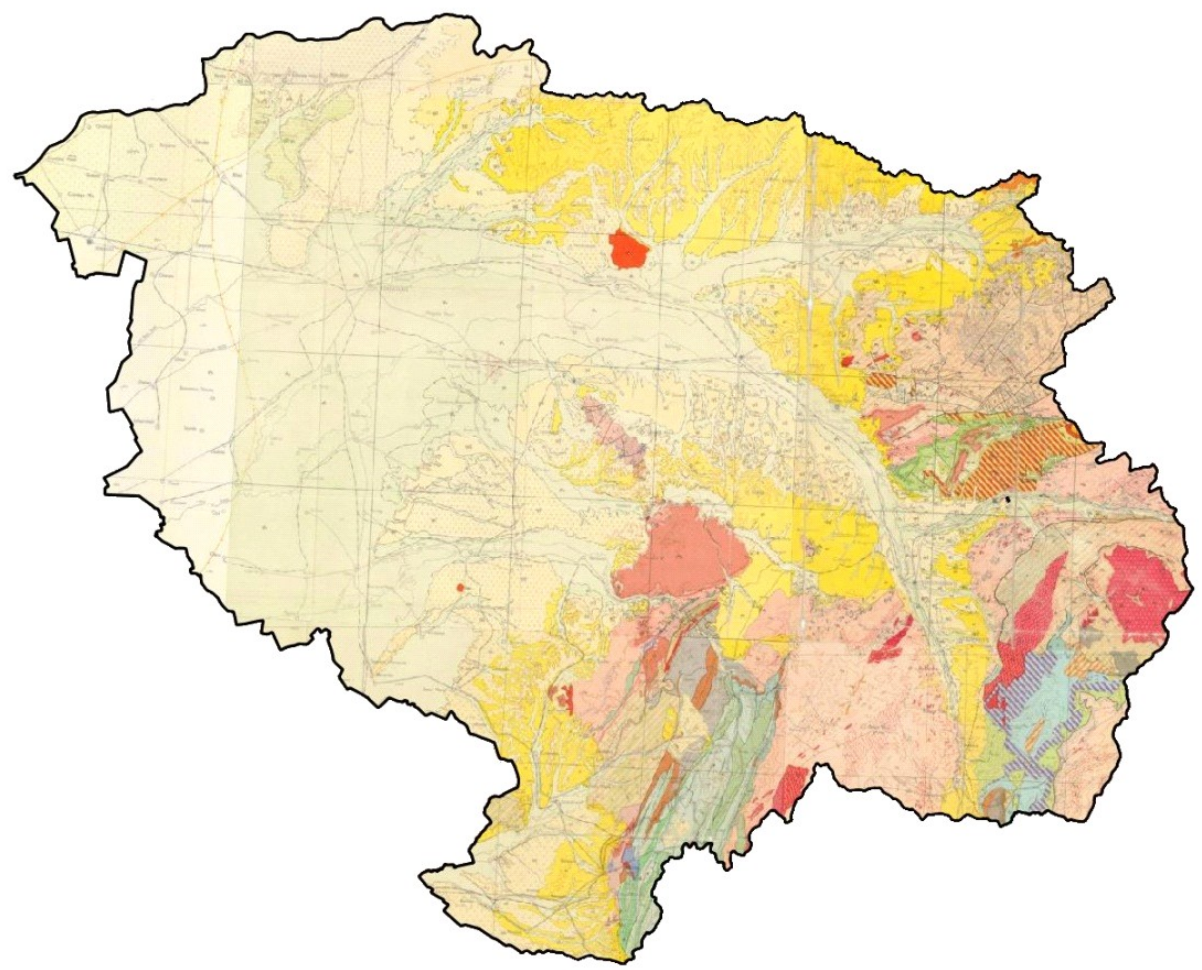

Figure 2: The Timiş River catchment area geology. (geo-spatial.org, 1: 200000 - modified). Legend - sedimentary rocks:

$p_{2}$ Gravels, sands, clays

qh $\quad$ Gravels and sands

qpishth Loess deposit

$p p_{3}^{3} \quad$ Gravels, sands and clays (red clay)

qp? Gravels and sands

$p_{3}^{1} \quad$ Gravels and sands

$p_{2}^{2} \quad$ Gravels, sands, clays

pn Marls, sands and gravels

whoss Sands, clay sands, sandstones, conglomerates

brap Hexacorals limestones

Marly limestones and schists

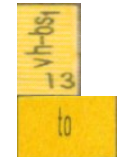

Marls, gravels

Clays, sands, tuff, sandy limestones

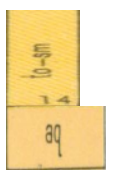

Gravels

Conglomerates, sandstones , clays

sn Marls

( 1 Conglomerates, sandstones , red clay shale, agglomerated porphyry Conglomerates, sandstones and red clay

Conglomerate sandstones

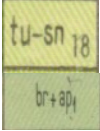

Limestones

88-0 Limestones with silicious accidents, marly limestones, sandstones

4. Conglomerates, sandstones, clay schists, coals 
Limestones, sandstones, conglomerates

axth : Lythographic limestones, nodular, dolomitic limestones, marl lens limestones and marls

ord- Limestones with siliceous accidents, marly limestones, sandstones

4. Conglomerates, sandstones, clay schists, coals

brag Hexacorals limestones

ne Marls, limestones and schists

$J_{2} \quad$ Limestones, sandstones, conglomerates

axth : Lithographic limestones, nodular limestones, dolomitic limestones, limestones with silex and marl lenses magmatic rocks:

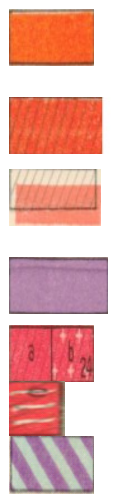

Basalt $\beta\left(\mathrm{qp}_{1}\right)$

Diorite $\delta\left(\mathrm{Pq}_{1}\right)$, Granogabbro $\omega\left(\mathrm{Pg}_{1}\right)$

Granite $\gamma\left(\operatorname{Pg}_{1}\right), \gamma \delta$ Granodiorite $\left(\operatorname{Pg}_{1}\right), \gamma$ $\delta \pi$ Porphyric Granodiorite $\left(\mathrm{Pg}_{1}\right)$

$\beta$ Basalts and associated rocks $(J)$

r Granitoide (Pz), b- Granite $\gamma(\mathrm{Pz})$,

e - Gneiss facies (fg)

Sedimentary volcanogenous formation (J) (sandstones and black clays associated with spilites, keratophyres, alkaline tuffs) metamorphic rocks:

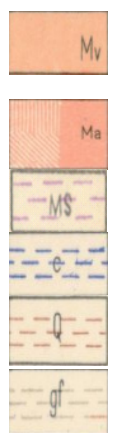

Phyllites, sericitous-chloritous Schists

Micaschists and Paragneiss

Metaserpentines

Crystalline Limestones

Quartzites

Graphitous Schists
Conglomerates, sandstones with coal clays, bituminous clays with sphaerosiderites and marls

Conglomerates with gabbro elements

$\mathrm{C}_{229}$ Ardesian argillites, diabases

$C_{3}$ Conglomerates, sandstones, clays

$c_{3}$ Conglomerates, sandstones, clays with coal interlayers

As: P Phyllites, tuffogenous green sediments

Micaschists, paragneiss

$\mathrm{P}<33_{33}$ Tulisa series

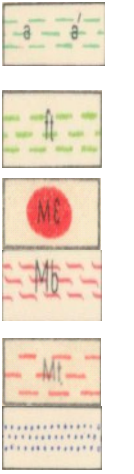

Amphibolites, a-

Metagabbros

Tuffogenous green

sediments

Pegmatites

Metablastic Migmatites

Metatectic Migmatites

Diaphtoresis areas

Magmatic metamorphism

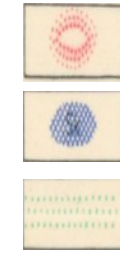

Contact halos: Corneans

(co), Contact Marbles (c)

Skarns

Autometamorphic rocks

Genetic types of Quaternary deposits

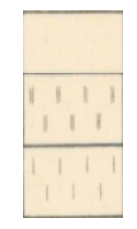

Fluvial deposits

Deluvial deposits

Proluvial-Deluvial Deposits 
From a geomorphologic point of view, the Timiş River catchment area is characterized by four relief forms: the mountain area, the Timiş-Cerna tectonic depression, the western hills (the hills of Pogăniş and Lugoj) and the Western Plain (the Lugoj plain and the Timiş plain).

The mountain region. The Timiş River originates in the Semenic Mountains area, part of Central formation of Munceii Bănăţeni, north of the Nera Corridor, and forms a distinct unit in the Banat Mountains, being separated on three sides by depressionary units and tectonic corridors: Ezeriş-Brebu Depression and Pogăniş Hills (North), Timiş Corridor and partially Cerna (East) and Almăj Depression in the South. These mountains are mainly made of crystalline rocks formed over geological times. The crystalline schists were metamorphosed in the Baikalian and Hercynic mountains genesis, during the Neosoic functioning as land, when the action of subaerial factors resulted in a rather intense shaping and forming of the erosion surfaces. Downward movements from Badenian and prolonged erosion led to the formation of heavy ridges, sometimes rounded, with heights below $1450 \mathrm{~m}$ (1447 m in Piatra Goznei), this situation giving them ample habitation opportunities (Pop, 2002).

Depression region. Timiş-Cerna Corridor. Is an inflectional lower unit between the Southern Carpathians and Western Carpathians, with one of the most favourable positions regarding humanization as demonstrated by the material traces of habitation from Neolithic (Caransebeş), and by the Dacian and Roman localities (Caransebeş, Mehadia, Teregova, etc.) as well as some of the oldest mining traces. It was formed by immersion, during the Helvetian and the Badenian, representing an elongated elbow that was related to Almăj and Haţeg depressions where there were deposited limestone, sandstone, gravel, sandy clays, the waters receding only in the early Quaternary (Pop, 2002). By deepening the rivers formed in this tectonic corridor (Cerna, Bela Reca, Mehadica, Bistra) in the lower erosion surface, today appearing as a marginal area, a well developed system of terraces was created (Roşu, 1973).

The hills region. West hills enter in the Western Carpathians following the Timiş corridor, of the former coastal plain of accumulation during the Pliocene, continued on land with continental accumulations of piedmont type. With the elevation of the Western Carpathians and the Pannonian Sea sedimentation, sediments formed high plateaux at first and "hills" afterwards. In some places, under the blanket of loose rocks (especially sand, clay, marl, piedmont accumulations) appear tougher rocks with the appearance of "knobs" that can be from either crystalline or volcanic schists (Mândruţ, 1993). They have altitudes between 200 and $300 \mathrm{~m}$, and altitudes higher than $300 \mathrm{~m}$ occur frequently in Lugoj Hills.

The hydrographical network widened slightly in the soft molasses strata, forming real bays that penetrate deep into the hills. Among rivers the most important is Timiş, along which the Banat Plain advances more toward east and forms the Lugoj Plain, with a wide opening to Caransebeş Depression, marking the largest geographical discontinuity between the Banat hills (Badea et al., 1992).

The plain region. The Plain of Banat is part of the Western Plain which, in its turn, is a subdivision of the Tisa Plain. It runs from the southern part of the Mureș Plain to the southern border of the country (Roşu, 1973) and represents nearly half of the western plain. The elevation is between 75 and $180 \mathrm{~m}$, and has a slight incline from East to the West, while the lower altitudes are located in areas of subsidence (Badea et al., 1992).

It was formed from the sedimentation of Pannonian Sea with sediments brought by rivers during the Neogene until recent time periods. It dried gradually since Pleistocene (the high plains) and Holocene (the low plains, the meadows). Lithologically speaking, it consists of sands, gravels, loess (high plains) and silt - more recent (in lower plains) (Mândruț, 1993). 
Given the genesis, the constituent formations and physical-geographical particularities, three field types are differentiated: low type, subsidential (the Plains of Timiş and Aranca), high type, on foothills (the Plains of Vinga, Lugoj and Bârzava) and intermediate type (the Plain of Jimbolia) (Munteanu and Munteanu, 1998).

From a climate perspective, the studied area belongs to temperate-continental climate, with Mediterranean and Oceanic type influences (Bradea et al., 1981). Because of its location in the south-west, the sector up to Caransebeş falls into Banat's subtype, with submediterranean type shades (Antonescu et al., 1981). Regarding the plains, there is a difference from the East (near the hills) to the West, besides the latitude difference from the South to the North. There is also a large variety of topo-climates and micro-climates as diverse landforms lead to a variety of climates. The topo-climate and micro-climate of natural subunits of Banat's plain are both complex and elementary (Soroceac, 2005).

The main climatic subtypes here are Western ocean-tinted subtype, Banat's Mediterranean-tinted subtype, Western Hills oceanic-tinted subtype and Medium mountain climate subtype.

In general, the average temperature ranges between $10-11^{\circ} \mathrm{C}$. Thermal regime in the coldest month varies between $0^{\circ}$ and $-3^{\circ} \mathrm{C}$. The entire area of Banat Hills and Timiş corridor is contained by 0 and $-1^{\circ}$ isotherms, $-1^{\circ}$ and $-2^{\circ}$ isotherms can be found throughout the western part of the Tisza Plain and the $-2^{\circ}$ and $-3^{\circ}$ isotherms include Western Hills and Banat Mountains. The thermal regime of the hottest month is contained inside the $18-22^{\circ}$ isotherms. Regarding rainfall, these are quite frequent, approximately $600 \mathrm{~mm}$ per year in Tisza Plains, and 700-800 mm per year in the Western Hills (Roşu, 1973).

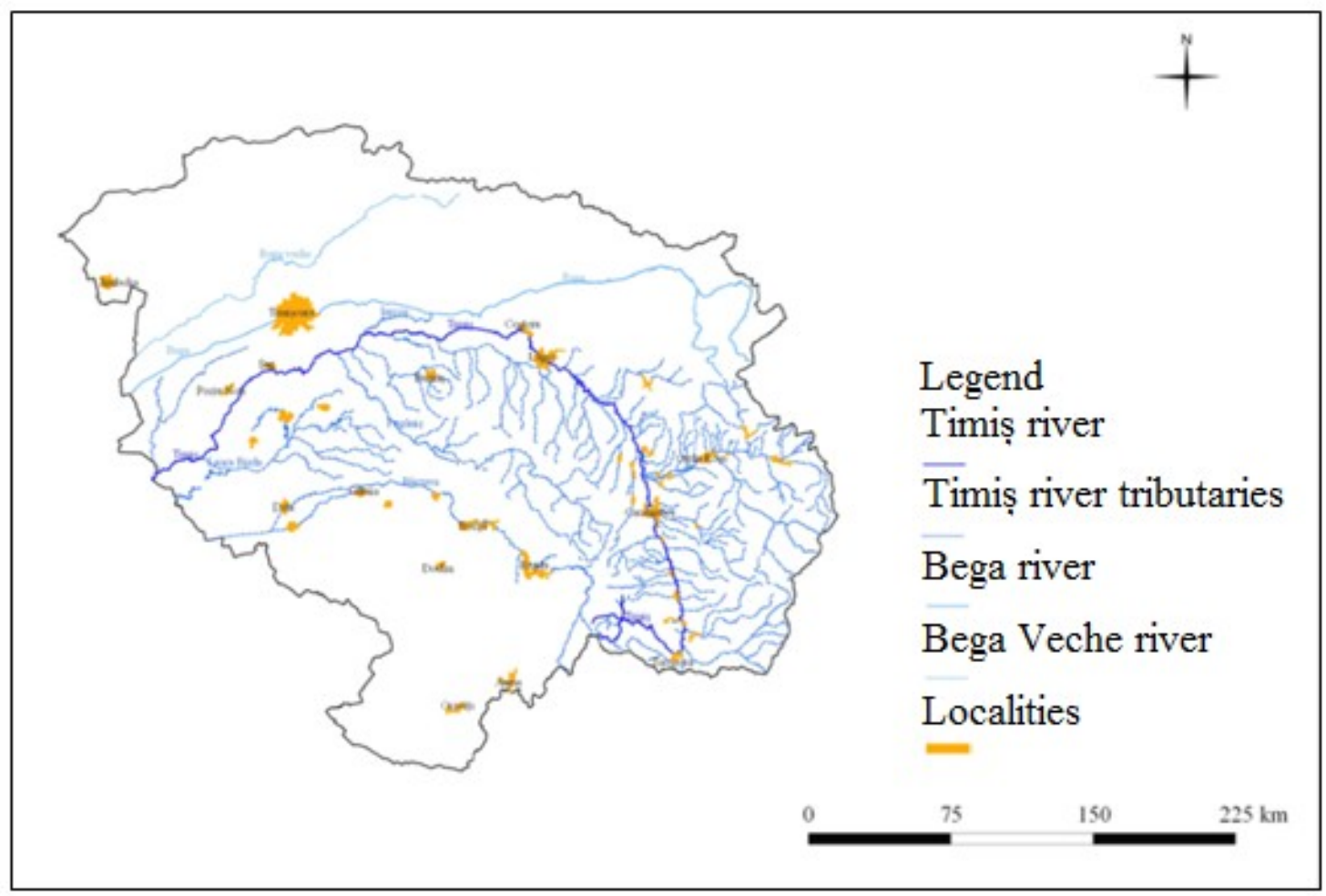

Figure 3: The Hydrographic basin of Timiş River, Romania. 
Timiş River (Fig. 3) is the main hydrographical artery in Banat, having the greatest expansion of all rivers. It springs from the eastern slope of the Semenic Mountains, from under the Piatra - Goznei Peak, at an altitude of $1135 \mathrm{~m}$ and flows into the Danube in Serbia, downstream of Belgrade at Pančevo. Timiş River basin has a total area of $7319 \mathrm{~km}^{2}$ of which $5248 \mathrm{~km}^{2}$ is located on the territory of Romania (Antonescu et al., 1981). Its total length is 358 $\mathrm{km}$, of which $241.2 \mathrm{~km}$ in Romania and $123 \mathrm{~km}$ in Serbia (Ujvári, 1972).

Its course is divided into three parts: the first part in the mountainous area, where it gathers small rivers, the second part is the Timiş-Cerna Gorge, a tectonic shell that separates the Banat Mountains among the Southern Carpathians (the Meridionals Carpathians). Here it receives tributaries from mountain chains like Țarcu Godeanu and Semenic Mountains, showing a relatively constant and consistent flow. Finally, the last part - after receiving the most important tributary - Bistra $\left(\mathrm{S}=919 \mathrm{~km}^{2}, \mathrm{~L}=60 \mathrm{~km}\right)$ (Teodorescu, 2008).

Its upper course has a typical mountainous aspect, with average falls of over $20 \mathrm{~m} / \mathrm{km}$ $(\max .37 \mathrm{~m} / \mathrm{km})$. In the mountain regions, Timiş River receives two relatively small but important streams Brebu $\left(\mathrm{S}=15 \mathrm{~km}^{2}, \mathrm{~L}=5 \mathrm{~km}\right)$ and Semenic $\left(\mathrm{S}=29 \mathrm{~km}^{2}, \mathrm{~L}=10 \mathrm{~km}\right)$, and after $25 \mathrm{~km}$ from the source it enters the Timiş-Cerna corridor. At its spring its waters and that of its tributaries are captured by the Semenic Channel. The minor depression at Teregova is a real market for water gatherings.

Here, Teregova River $\left(\mathrm{S}=51 \mathrm{~km}^{2}, \mathrm{~L}=15 \mathrm{~km}\right)$ also arrived from the Semenic massive, a small creek - Criva in the valley of which the road to the Eastern Gate (Pasul Domaşnea) winds its way and finally Hideg or Râul Rece River $\left(S=171 \mathrm{~km}^{2}, \mathrm{~L}=34 \mathrm{~km}\right)$ that springs below the peaks of Ţarcului Mountains (Căleanu - $2190 \mathrm{~m}$ ), all flow in Timiş River. Râul Rece River has its origin near the springs of Seş River, from the cirque, with the late melting of snow, which imprints on the Timiş River the first characteristics of a Carpathian regime type, which will increase downstream especially after receiving Bistra River.

Downstream of the confluence with river Hideg, Timiş River enters the Armeniş Gorge, and then the valley widens gradually acquiring a more pronounced ramble character with relatively high slopes $(4-8 \mathrm{~m} / \mathrm{km})$. The corridor ends downstream of Caransebeş where in the piedmont plain the ramble is emphasized even more in terms of an average slope of 1.6 $\mathrm{m} / \mathrm{km}$ between Caransebeş and Lugoj.

Along the corridor sector, Timiş River receives in a symmetrically manner tributaries from the Semenic and from Țarcu Mountains, but the right tributaries are more developed. The first tributary, Feneş River $\left(\mathrm{S}=137 \mathrm{~km}^{2}, \mathrm{~L}=24 \mathrm{~km}\right)$ with its tributary Pârâul Alb $\left(\mathrm{S}=64 \mathrm{~km}^{2}\right.$, $\mathrm{L}=24 \mathrm{~km}$ ) have their origin near the Hideg springs, but from the western slopes. Like the Hideg River, their average slopes are higher, ranging around $45-56 \mathrm{~m} / \mathrm{km}$, representing good areas for hydraulic structures. Downstream, until Caransebeş, Timiş receives only small tributaries, which spring from Sarmatian deposits such as Armeniş, Ilova, Groaşa, Bolvaşniţa and Zlagna.

From Semenic Mountains, Timiş River collects from its corridor sector the rivers Slatina $\left(\mathrm{S}=27 \mathrm{~km}^{2} ; \mathrm{L}=11 \mathrm{~km}\right)$, Goleţul $\left(\mathrm{S}=43 \mathrm{~km}^{2} ; \mathrm{L}=15 \mathrm{~km}\right)$, Bucoşniţa, Cerneţul and Valea Mare $\left(\mathrm{S}=51 \mathrm{~km}^{2} ; \mathrm{L}=13 \mathrm{~km}\right)$.

At Caransebeş the final tributary of the western flank of the Tarcu massif flows into Timiş River, Sebeş River $\left(\mathrm{S}=142 \mathrm{~km}^{2}, \mathrm{~L}=23 \mathrm{~km}\right)$, spring from the glacial cirques, and then Timişul receives its largest tributary Bistra River.

After the confluence with Bistra, the fan-shaped alluvial cone of Timiş starts close to the border with Serbia. In the area of the cone there is a gradual deviation of the Timiş to the right, largely because of its tributaries developed mostly on the left, but probably due to neotectonic movements, as the phenomenon was noticed in the case of Bega River. The 
abandoned courses that are parallel to the Timiş River and who eventually flow into it are Măcicaşul $\left(S=77 \mathrm{~km}^{2} ; \mathrm{L}=20 \mathrm{~km}\right)$, Vâna Secănească $\left(\mathrm{S}=72 \mathrm{~km}^{2} ; \mathrm{L}=13 \mathrm{~km}\right)$, Ştiuca and Timişina $\left(\mathrm{S}=434 \mathrm{~km}^{2}, \mathrm{~L}=47 \mathrm{~km}\right)$ all on the left. The last collects also from the left the rivers Sudriașul, Faţa, Cinca, Dicşanul and Cherăstrău, acting as a subpiemontan river collector. The tendency to deviate to the right of the Timiş is betrayed by its abandoned left arm, Timişul Mort, which was once the main course of the river. The conclusion of this process was hastened by the Timiş River embankments and other improvement works that have adapted to the natural process trend.

The left hills are largely drained by river Pogăniş $\left(S=696 \mathrm{~km}^{2} ; \mathrm{L}=100.2 \mathrm{~km}\right)$, which has an average gradient of $6.6 \mathrm{~m} / \mathrm{km}$, a relatively poor drainage and ample digression on Valeapai - Ersig and Duboz - Otveşti sectors. Finally, in the plain sector where it receives the waters of Pogăniş River, Timiş River has much lower slopes of $2.43 \mathrm{~m} / \mathrm{km}$, and slightly downstream they already fall below $1.0 \mathrm{~m} / \mathrm{km}$, so that at the border they get at $0.24 \%$. This last tributary with a typical character of plain is river Lanka - Birda, a channelled river $(\mathrm{S}=485$ $\mathrm{km}^{2}, \mathrm{~L}=45 \mathrm{~km}$ ), which has longitudinal slopes less than $0.18 \mathrm{~m} / \mathrm{km}$.

Out of the tributaries of the right of Timiş River in the piedmont sector we mention the rivers Calova, Macioviţa, Vălişoru and Nădragul $\left(S=164 \mathrm{~km}^{2} ; \mathrm{L}=33.6 \mathrm{~km}\right)$ which penetrates to the core of the Poiana Ruscă massif. At the confluence of Cornetului with Nădragul the metallurgical plants of Nădrag can be found.

At Coşteiu, from Timiş River, the flow supply channel of Bega River is derived, at Hitiaş it flows into the discharge channel of Bega channel and near Drăgşina it receives his last right tributary - Iarcoş River.

In the piedmont plain of Timiş River, extensive hydro facilities have been made, given the large floodplain area (about $1000 \mathrm{~km}^{2}$ ) and the existence of groundwater near the surface. (Ujvári, 1972)

\section{Historical significant changes in Timiş River basin}

Timiş River, previously called Themesius: ad Themesium amnem (form used by Cantemir and Bonfinius) or Titius: ad ripas Amnisos titi/Tibiscus (form used by Michael Riccio Neapolitanus) or Tibisis (form used over 2000 years back by the Romans), (Florentina and Olteanu, 2004) is the main river of the southwest part of Romania. It springs from the Semenic Mountains plateau and after passing the "Trei Ape/Three Waters" dam it digs deep and narrow valley on the NW-SE direction in the crystalline schists of Semenic its course having a strong torrential, with large slope drains $(20-25 \mathrm{~m} / \mathrm{km})$. Downstream, Timiş's bed begins to expand across the depression corridor of Caransebeş (Antonescu et al., 1981). At Coşteni, Timiş River enters its lower course, which mostly overlaps the digression plain. In this area the river valley is wide, meandering and digress with a very low slope. The river has a pronounced tendency to deviate to the right, a process betrayed by its abandoned arms (Timişul Mort, Oldâcău and Vâna Opâru) (Munteanu and Munteanu, 1998).

Timiş River, together with Bega and Bârzava rivers, has always had deviations that ramble throughout the Timiş Plain and a part of the Lugoj fields. After damming and channelling, some traces of relatively recent courses still remained: Small Bega, Timişatul and Dead Timiş Bega Mică, Timişatul and Timişul Mort.

Old Timiş always digressed a series of cones that each follow from Lugoj Bay to the border and often mix their waters with Bega, to or in Timișoara's area. To the west, the ramble extends to Old Bega, and to the south to Delibat and Alibunar's swamps (Serbia) (Posea, 
2002). In the past all the surrounding area of Timişoara city and lower Timiş was mostly swampy and muddy (Aldescu, 2010). The writings of Francesco Griselini in the eighteenth century support the words of Aldescu: "Numerous swamps and stagnant waters made in those times the air very unhealthy" or "The largest swamp begins at Mureș's disbursement into Tisza. (...) The other drained side, extends inside Timișoara's district, from Clarii, Crnja and Checea to Itbej and Pardan. Begheiul (Bega) goes through this part of the swamp with its sinuosity". (Griselini and Feneşan, 1984)

Mehmed Raşid's chronicles written in the XVII'th century relating the 1695 fight of Lugoj city, describe the area between Caransebeș city as a marshy place "except that Timiş river surroundings (...) were full of swamps. In the battle's description, is also described the surroundings of Lugoj city: "The place chosen by Veterani was situated at 2,750 m south-east from Lugoj city, in a place called "At city's tsarina" a muddy land situated on the left side of Timiș River, at an altitude of $124 \mathrm{~m}$, crossed from south-east to north-east by the Ştiuca creek". A description of the area appears in Silahdar Fîndliklîli Mehmed Aga fight chronicles, "Veterani's forces were placed about an hour before the city of Lugoj, on Sebeş's road, with its right side resting on the heads of two large swamps and its left side on a flowing river (Groza, 1995).

Currently wetlands have disappeared due to hydro technical works carried out with different economic purposes. The first hydraulic works began after 1716. After the reconquest of Banat by the Habsburg Empire (1716), there were allocated considerable sums to "drain the swamps and marshy waters in rivers, and from here to the Tisza and Danube, with the help of bigger canals, ditches aqueducts and artificial. "Maximilian Fremaut, an eminent hydraulic engineer conducted a series of works" (Griselini and Feneşan, 1984). Many of these works were made for drainage and flood protection, to improve navigation, to supply the city with drinking water and for industry. Another series of hydraulic structures were built in the $70 \mathrm{~s}$, consisting of reservoirs and polders to retain water during floods (Aldescu, 2010).

To demonstrate changes in the Timiş river's course in Caransebeş-Cruceni sector, we can consider the four map representations from the area:

- The first Josephine rising of Banat (1769-1772) Josephinische Landesaufnahme-detail;

- The third Josephine rising of Banat (1868-1880) Franzisco-Josephinische Landesaufnahmen - detail;

- A topographic map showing the situation in year 1996 - detail;

- A satellite map showing the situation in 2012 - detail;

From figures 4-38 it can be noted that in the years 1769 to 1772 until the present day, Timiş river has undergone many changes, mostly due to the regularization. The main changes occurred are the loss of its arms, cutting meanders and straightening course, embankments and the disappearance of wetlands. Compared to the years 1769-1772, the biggest changes occurred in Caransebeş city (Figs. 4-7), at the confluence with Bistra (Figs. 8, 9 and 11) and on the Găvojdia - Măguri (Figs. 16-19), Bazoş - Moşniţa Nouă (Figs. 24-27), Şag - Uliuc (Figs. 28-31), Cebza - Petroman (Figs. 32, 33 and 35) and the Gad - Cruceni (Figs. 36, 37 and 38) sectors. 


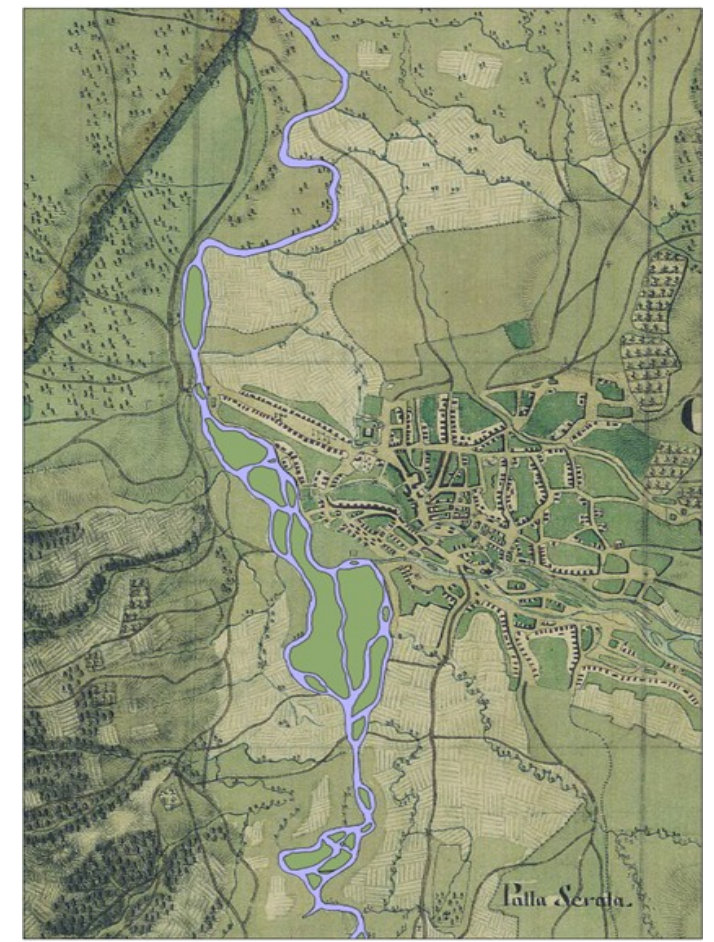

Figure 4: The first Josephine map rising Caransebeş detail.



Figure 6: Kind topographic - Caransebeş detail 1996.

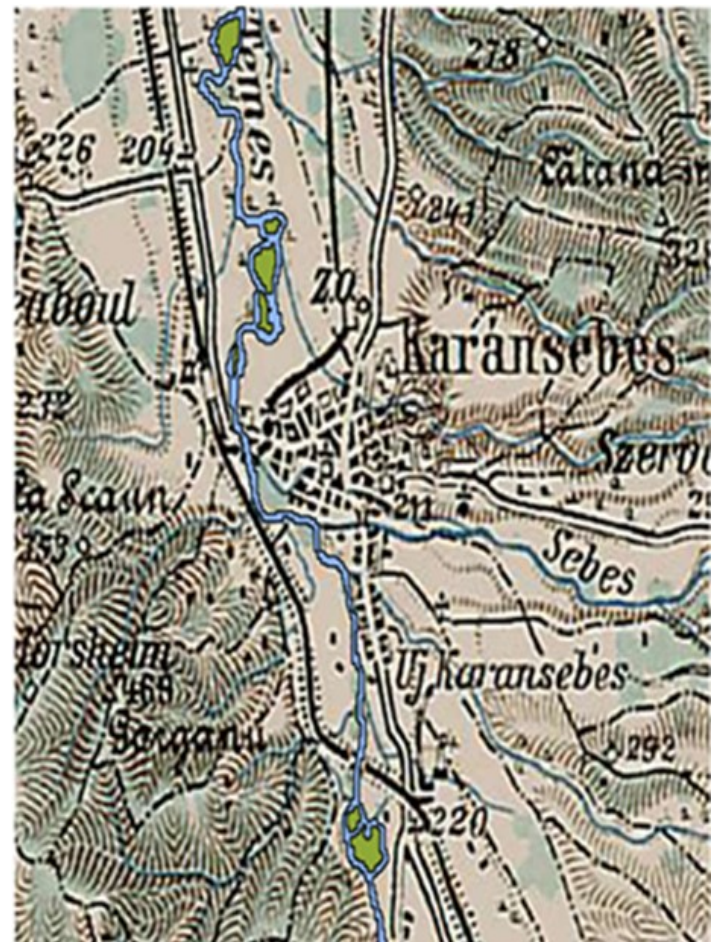

Figure 5: The third Josephine map rising Caransebeș detail.

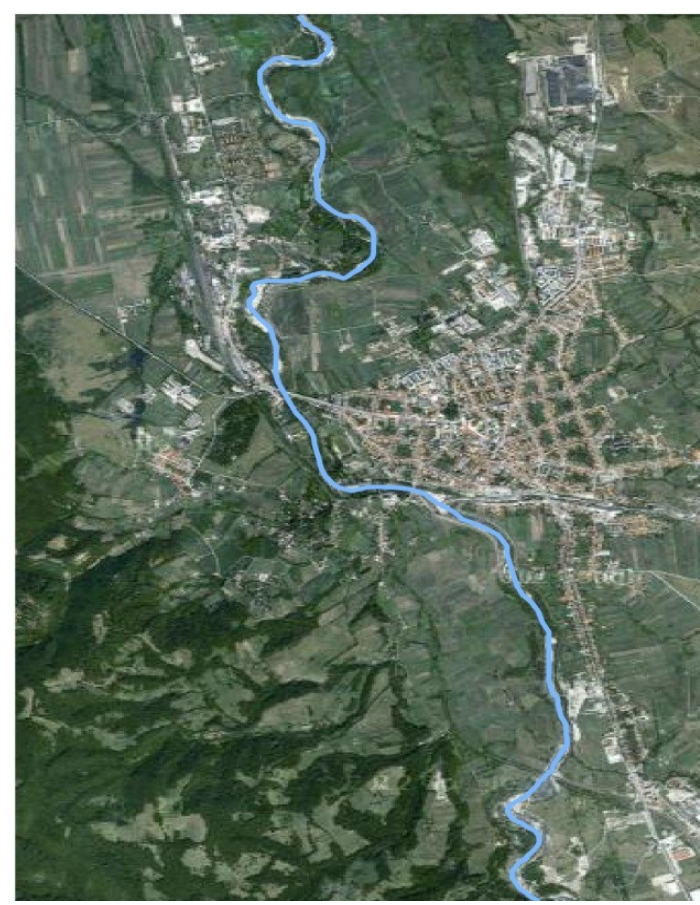

Figure 7: Satellite maps - Caransebeş detail 2012. 


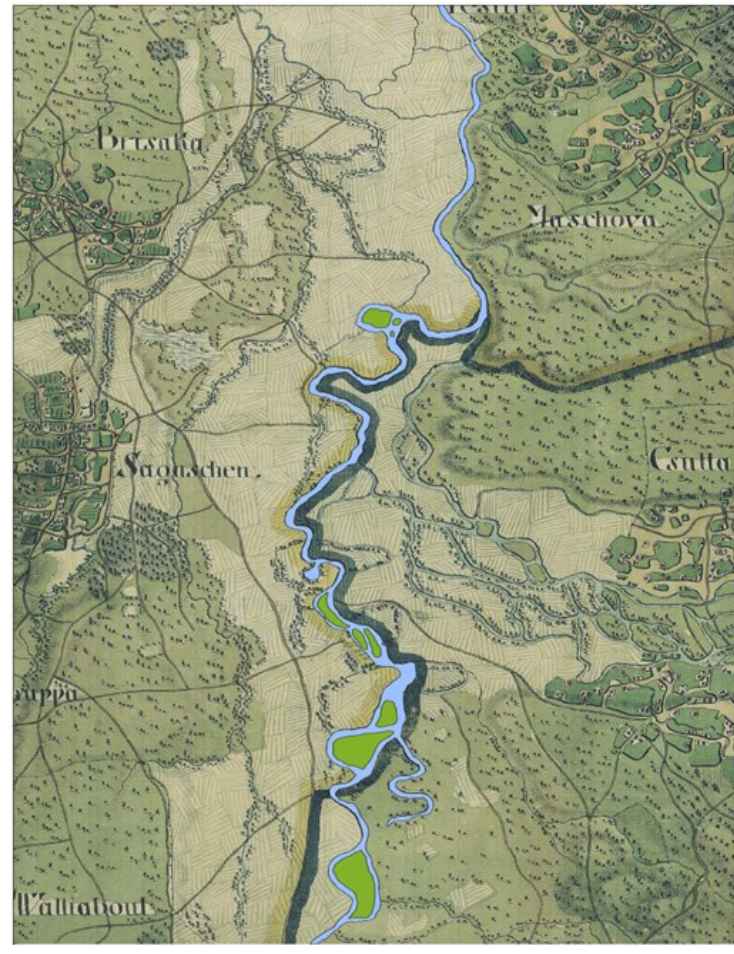

Figure 8: The first Josephine map rising: Confluence with Bistra - detail.

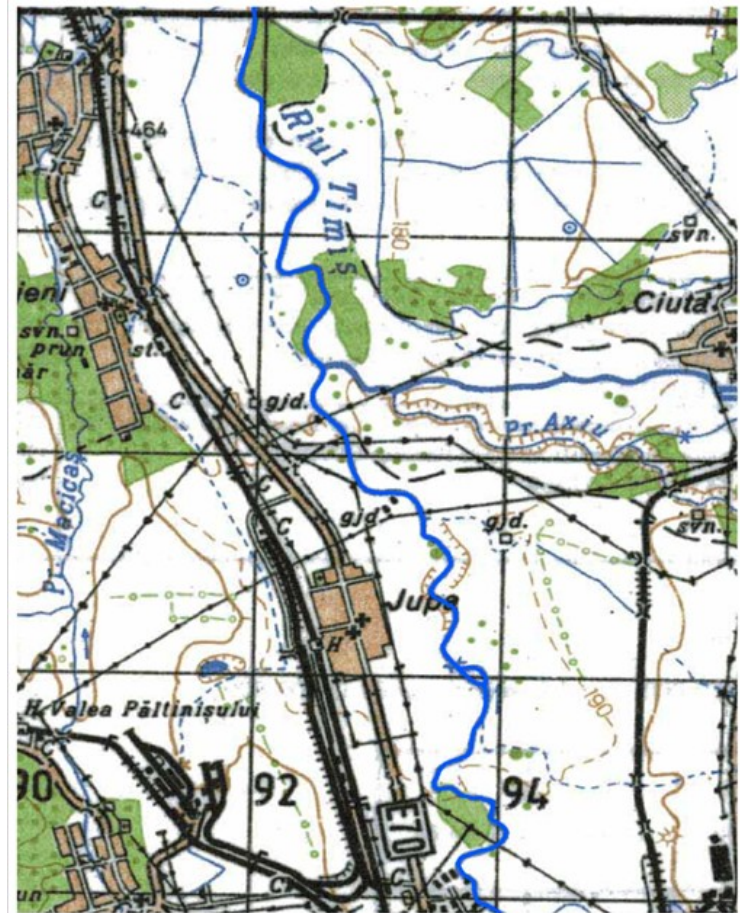

Figure 10: Kind topographic - Confluence with Bistra- detail 1996.

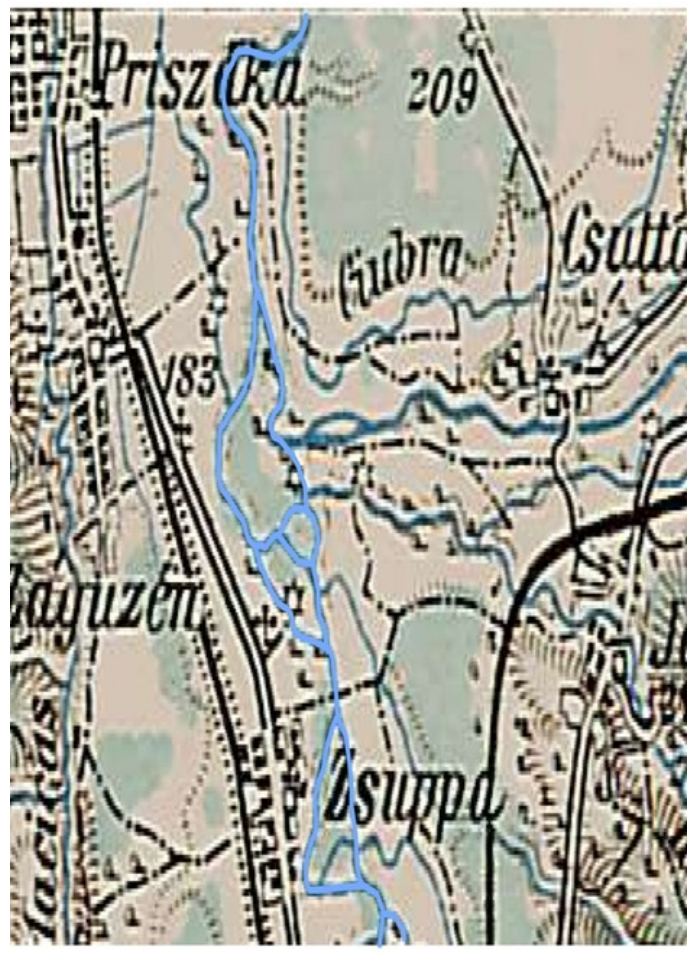

Figure 9: The third Josephine map rising: Confluence with Bistra - detail.

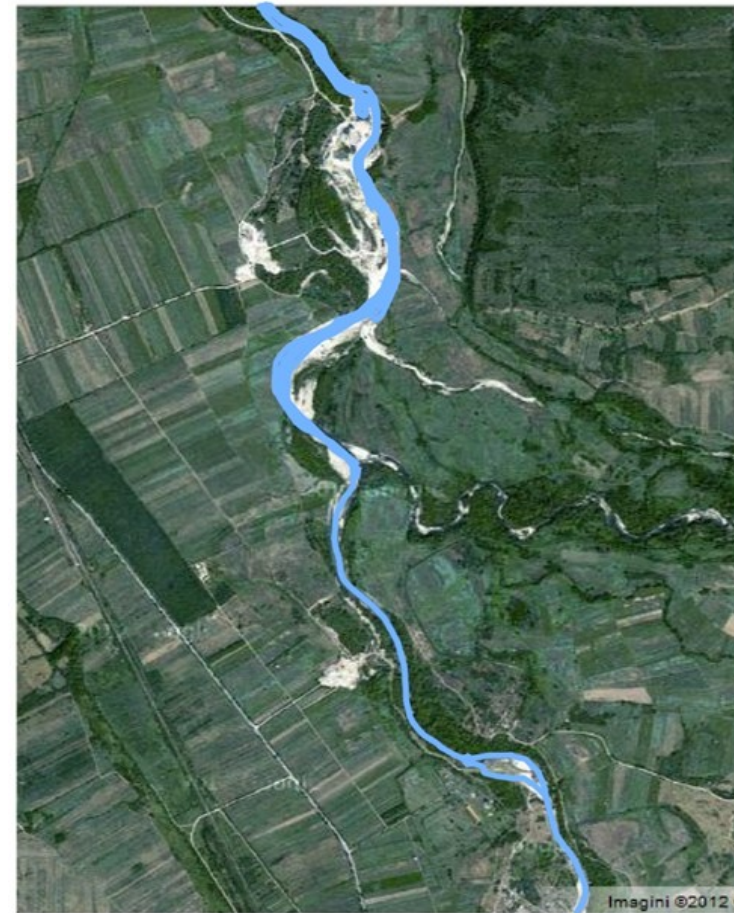

Figure 11: Satellite maps - Confluence with Bistra- detail - 2012. 


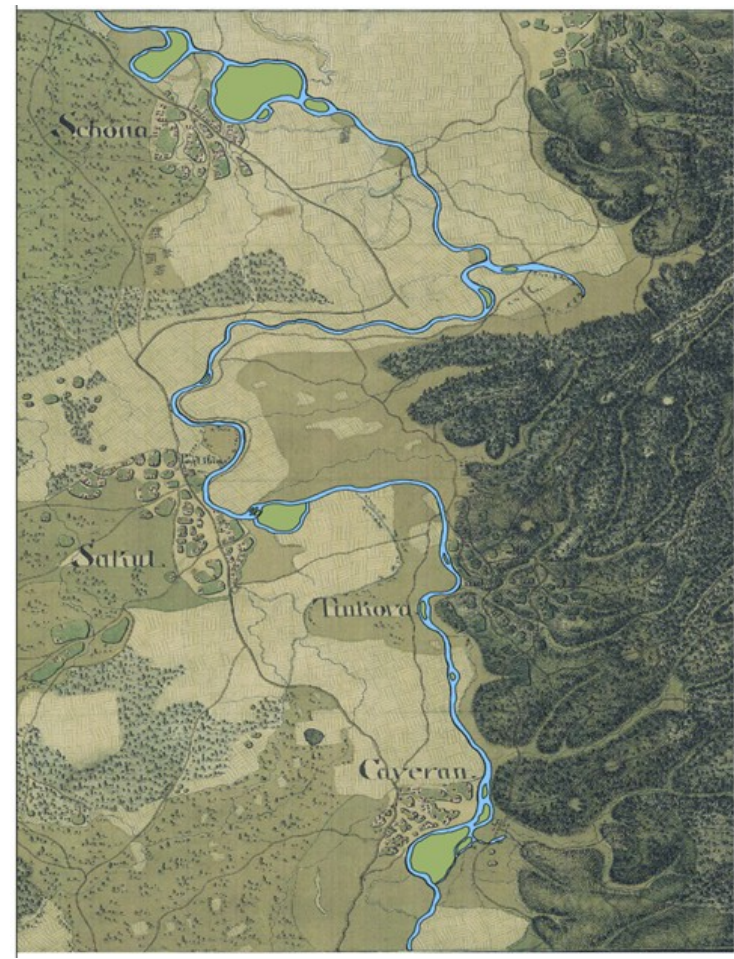

Figure 12: The first Josephine rising:

Constantin Daicoviciu - Jena - detail.

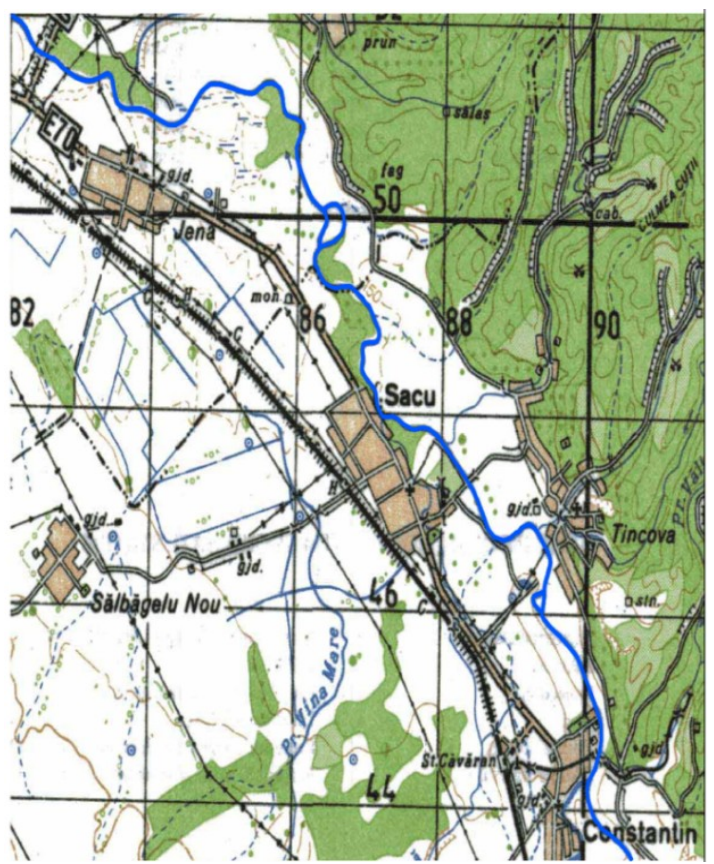

Figure 14: Kind topographic - Constantin Daicoviciu - Jena- detail 1996.

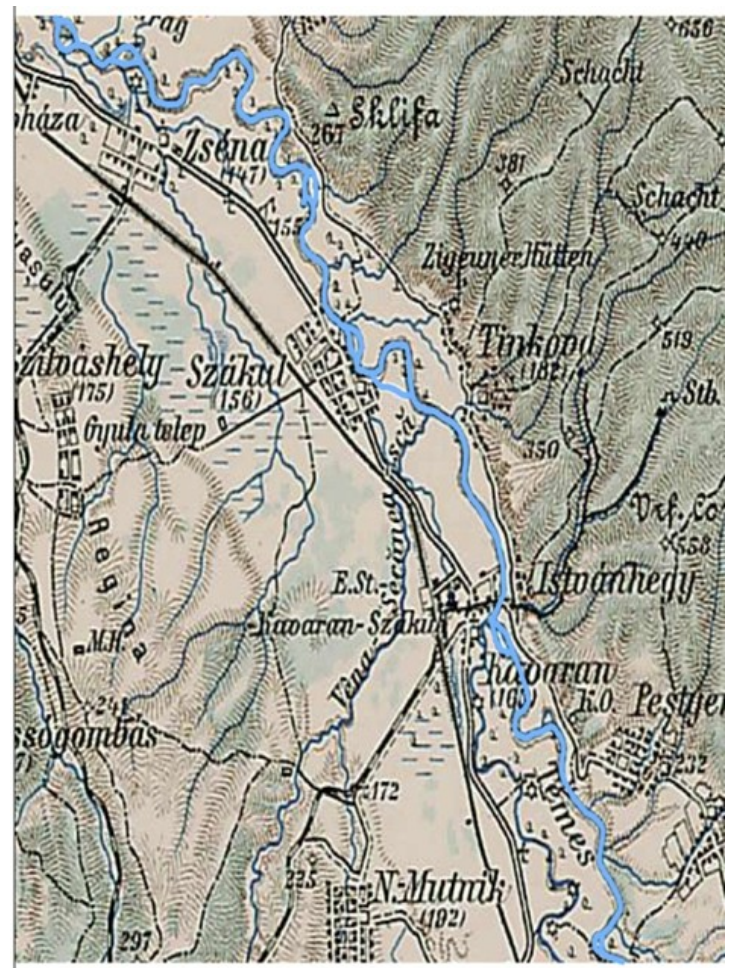

Figure 13: The third Josephine rising: Constantin Daicoviciu - Jena - detail.

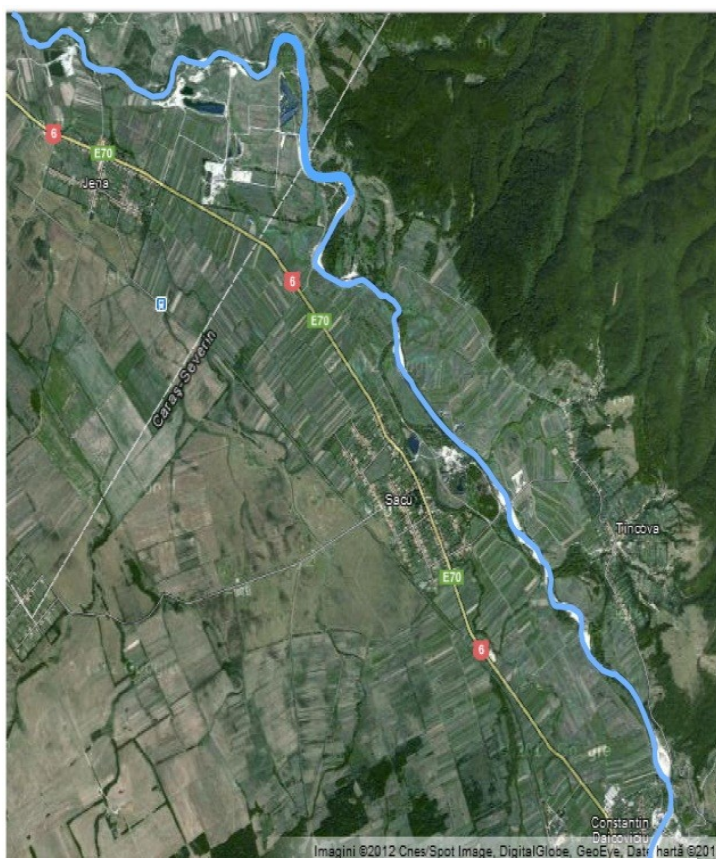

Figure 15: Satellite maps - Constantin Daicoviciu - Jena - detail - 2012. 


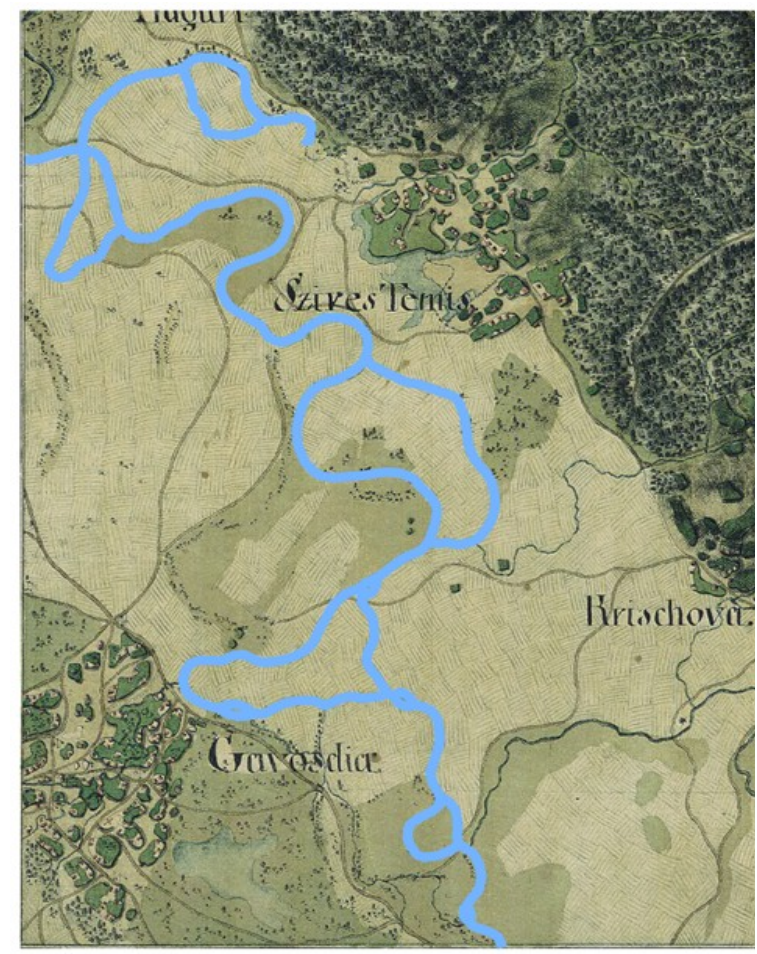

Figure 16: The first Josephine rising: Găvojdia - Măguri - detail.

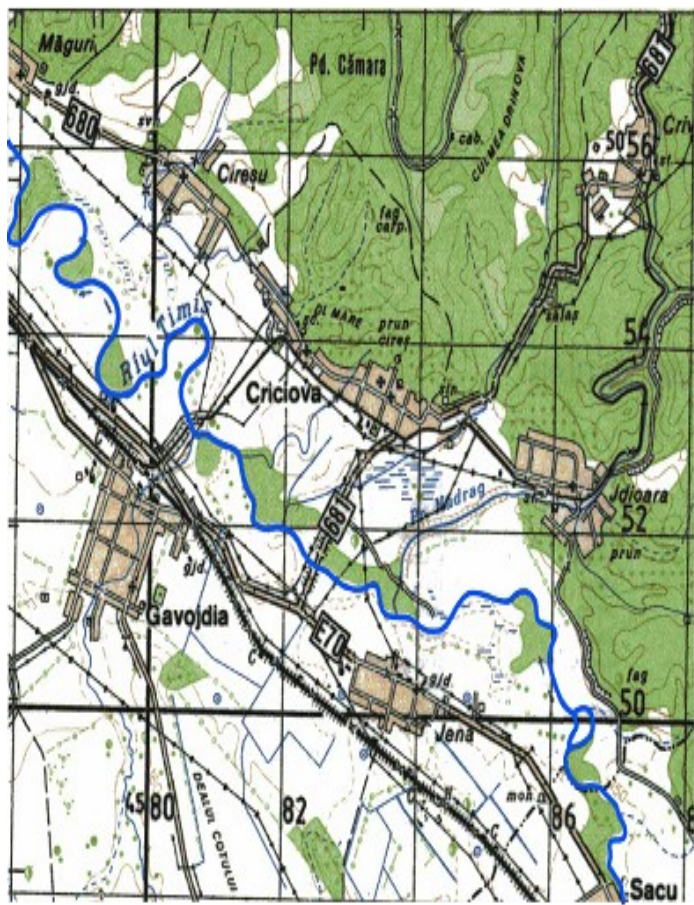

Figure 18: Kind topographic - Găvojdia Măguri - detail - 1996.

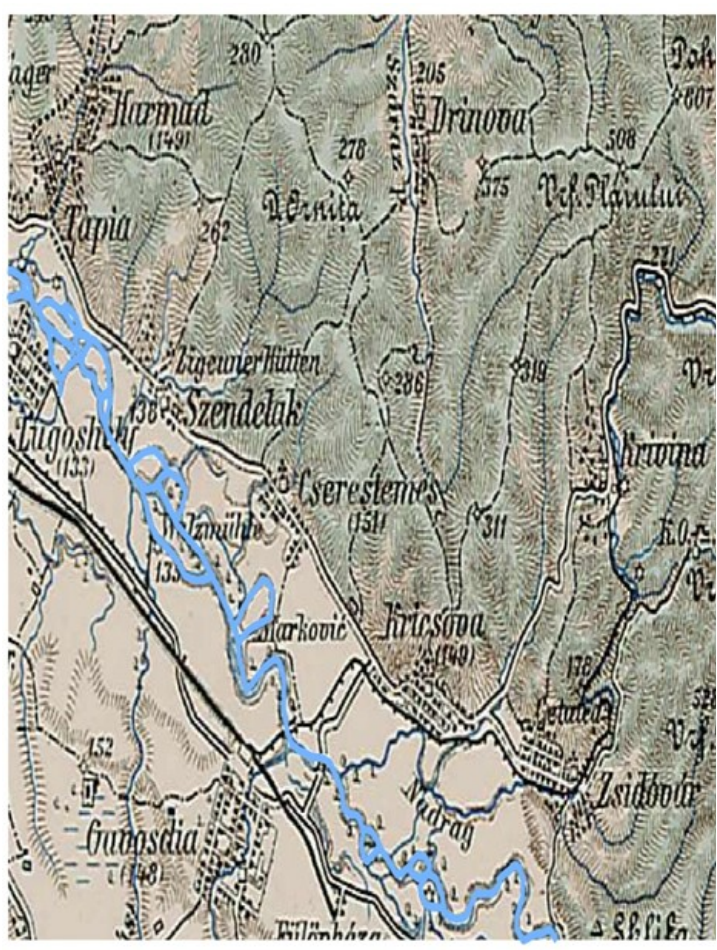

Figure 17: The third Josephine rising: Găvojdia - Măguri - detail.

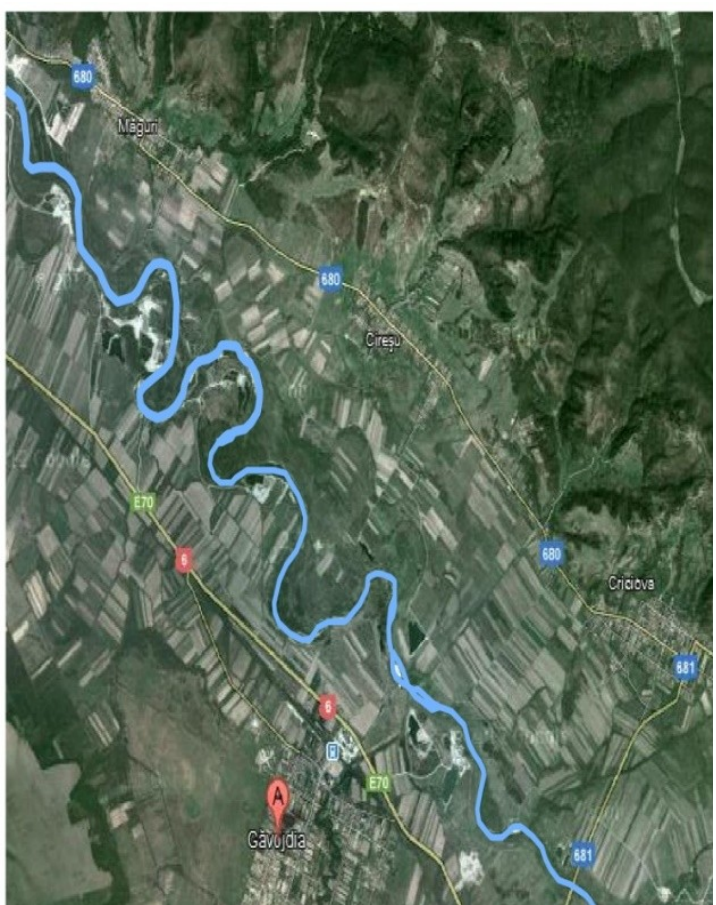

Figure 19: Satellite maps - Găvojdia Măguri - detail - 2012. 


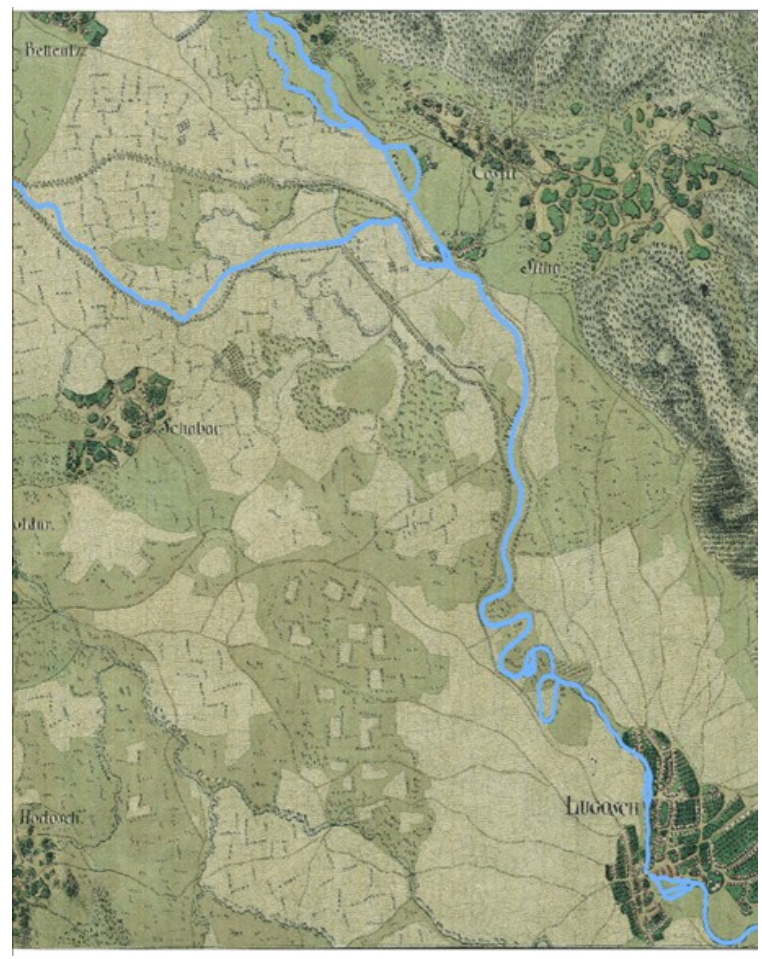

Figure 20: The first Josephine rising: Lugoj Coştei - detail.

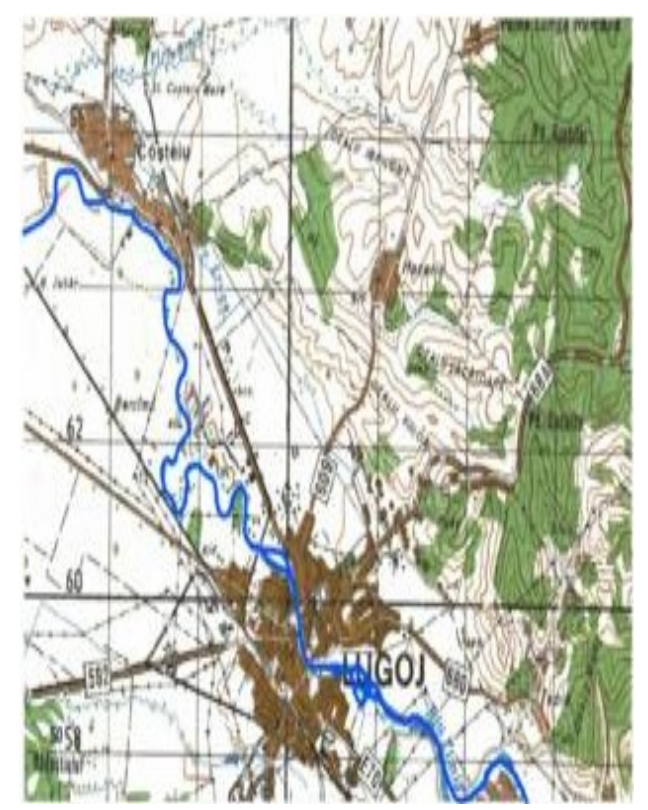

Figure 22: Kind topographic - Lugoj - Coştei - detail 1996.

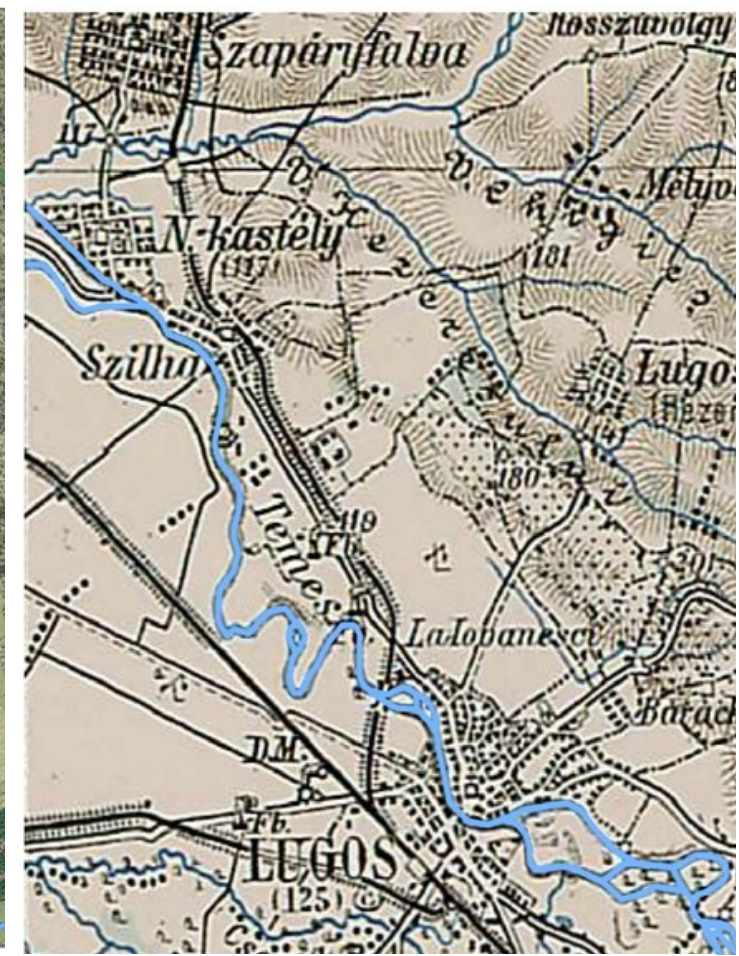

Figure 21. The third Josephine rising: Lugoj

- Coştei- detail.

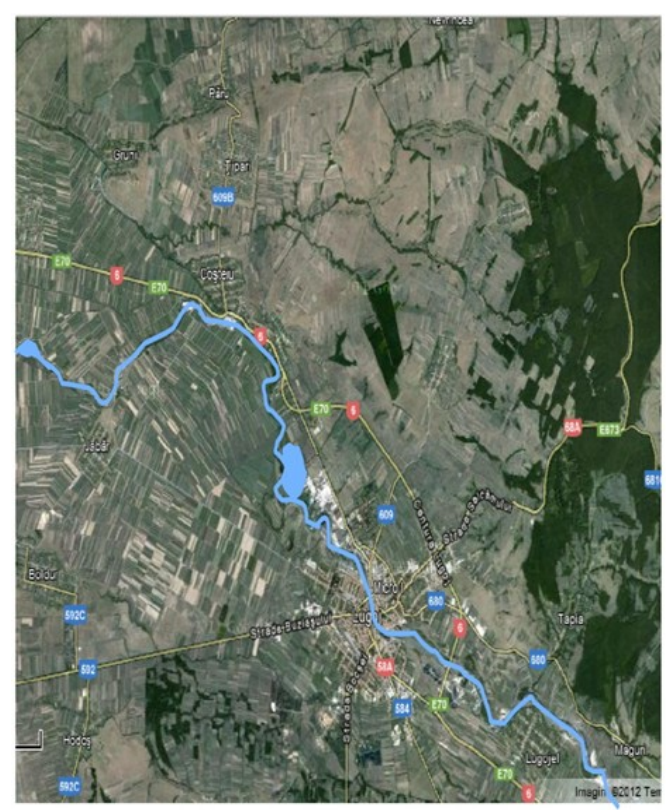

Figure 23. Satellite maps -

Lugoj - Coştei - detail 2012. 


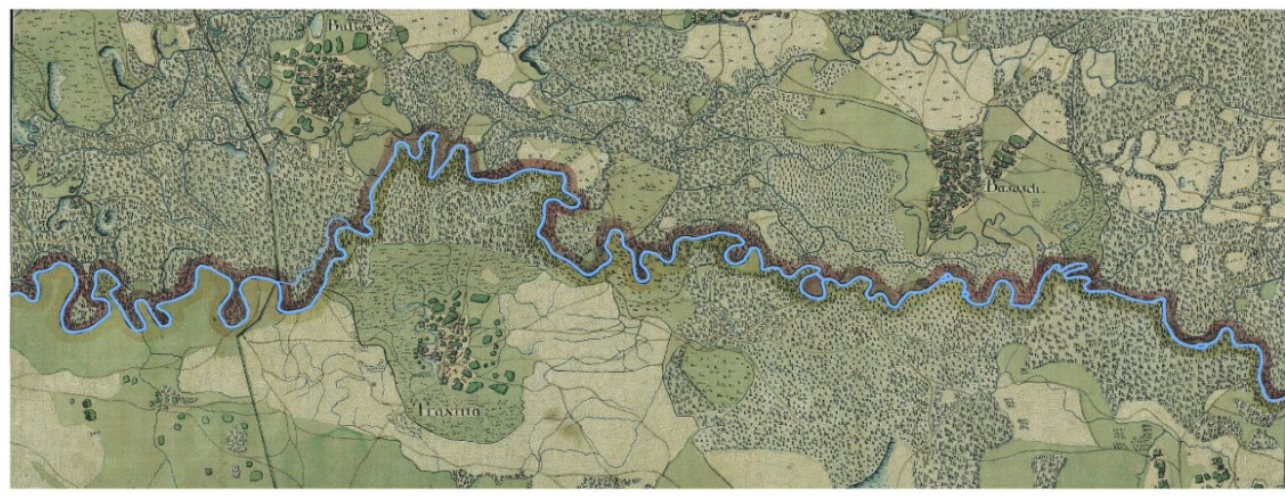

Figure 24: The first Josephine rising: Bazoș - Moșnița Nouă - detail.

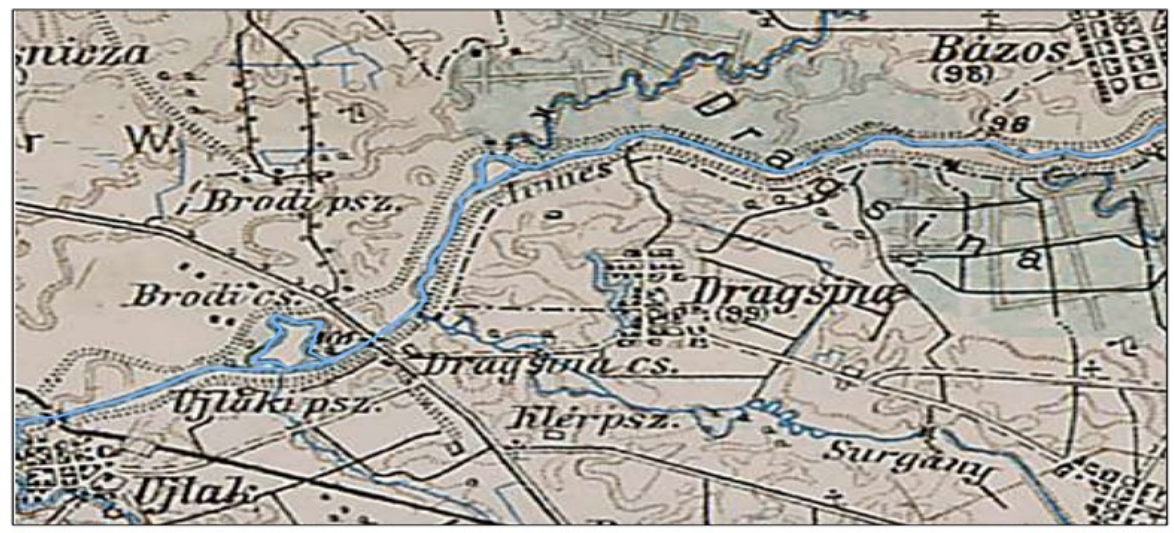

Figure 25: The third Josephine rising: Bazoș - Moșnița Nouă - detail.

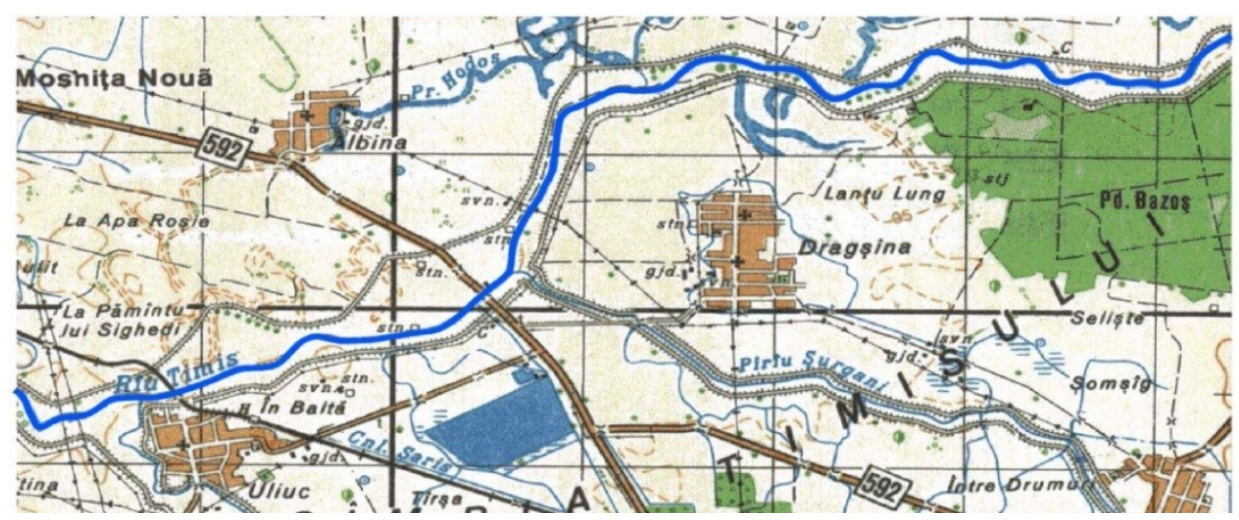

Figure 26: Kind topographic - Bazoș - Moșnița Nouă - detail 1996. 


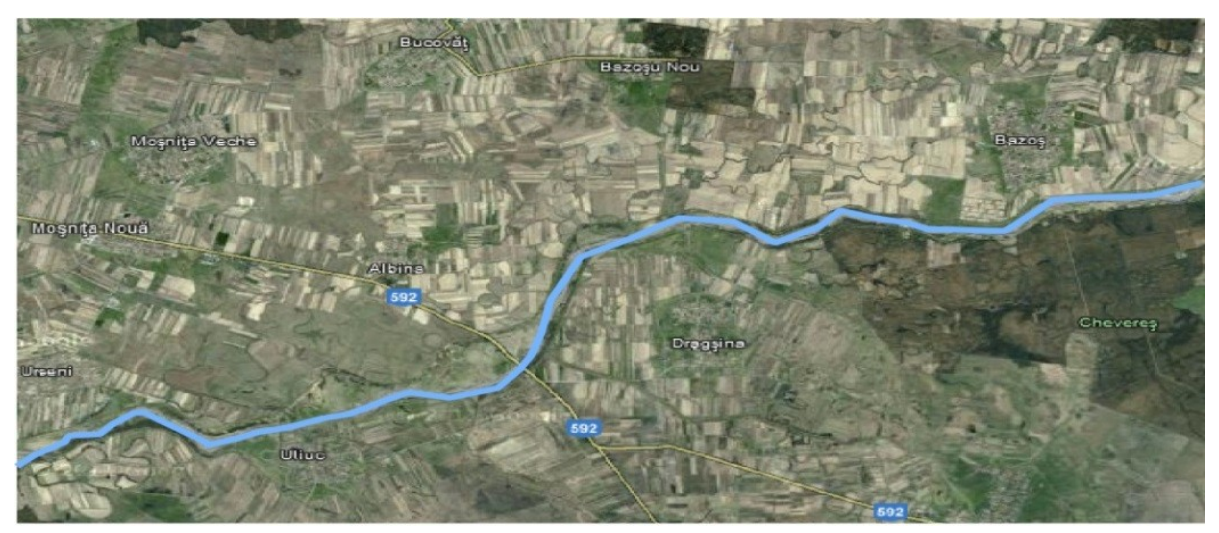

Figure 27: Satellite maps - Bazoș - Moșnița Nouă detail - 2012.

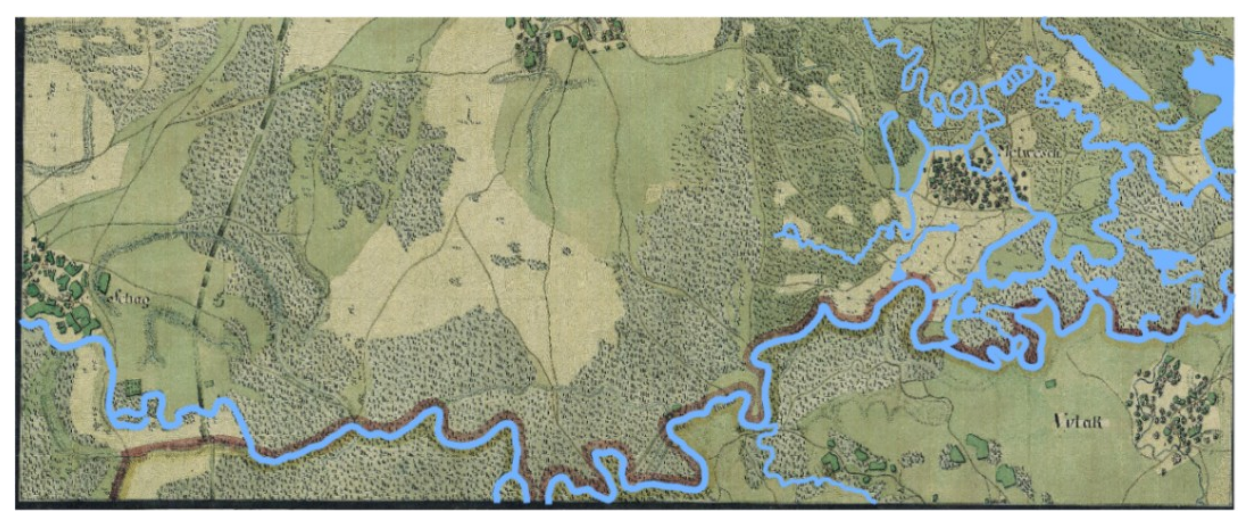

Figure 28: The first Josephine rising: Uliuc - Șag - detail.

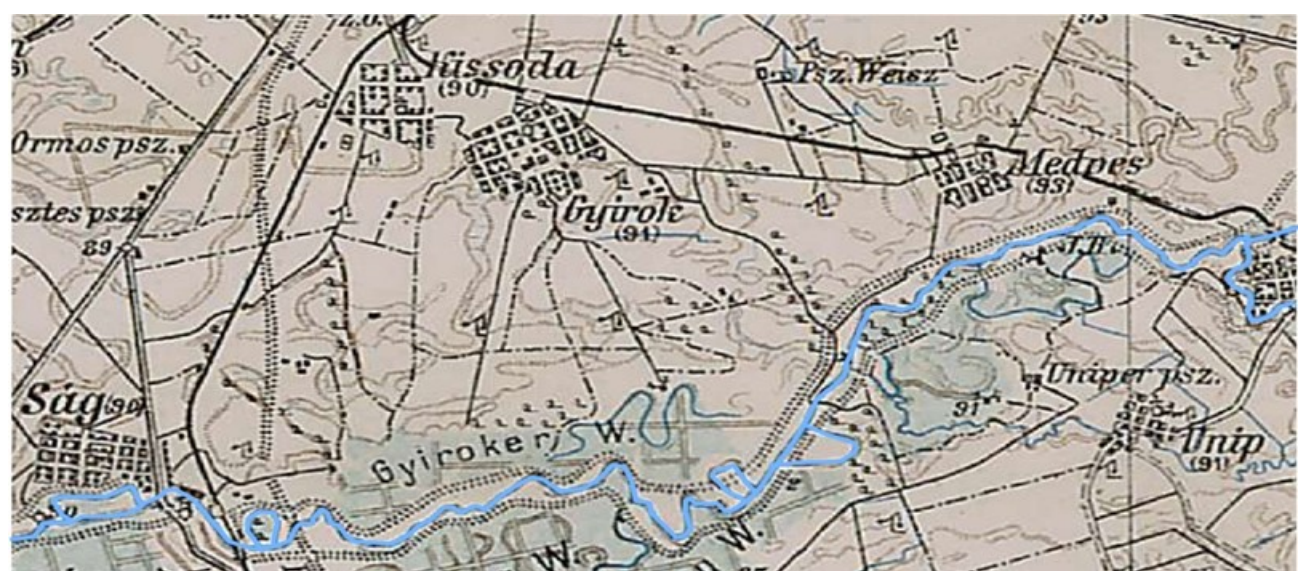

Figure 29: The third Josephine rising: Uliuc - Șag - detail. 


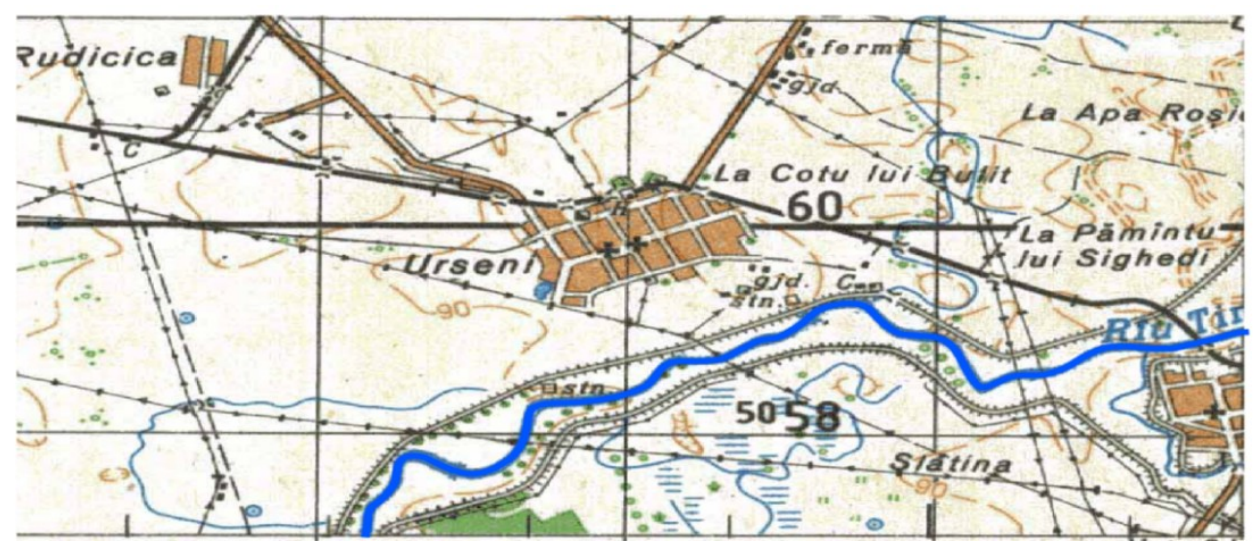

Figure 30: Kind topographic - Uliuc - Șag - detail - 1996.

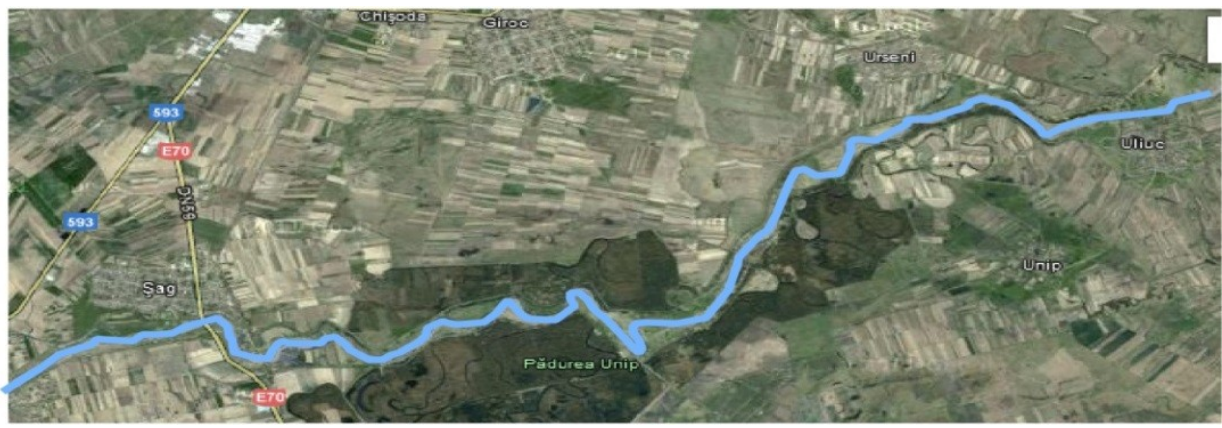

Figure 31: Satellite maps - Uliuc - Şag- detail - 2012.

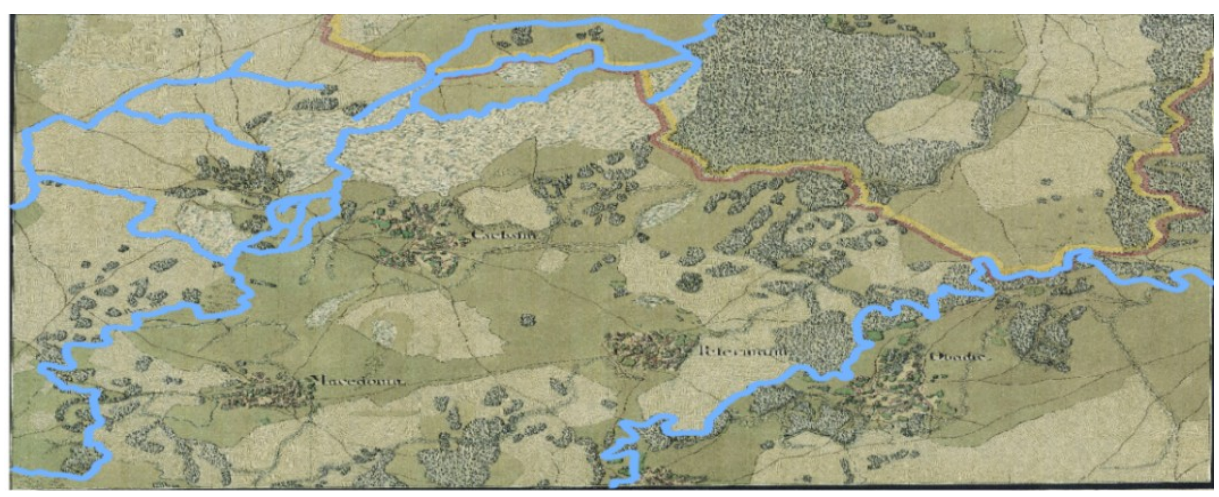

Figure 32: The first Josephine rising: Cebza - Petroman - detail. 


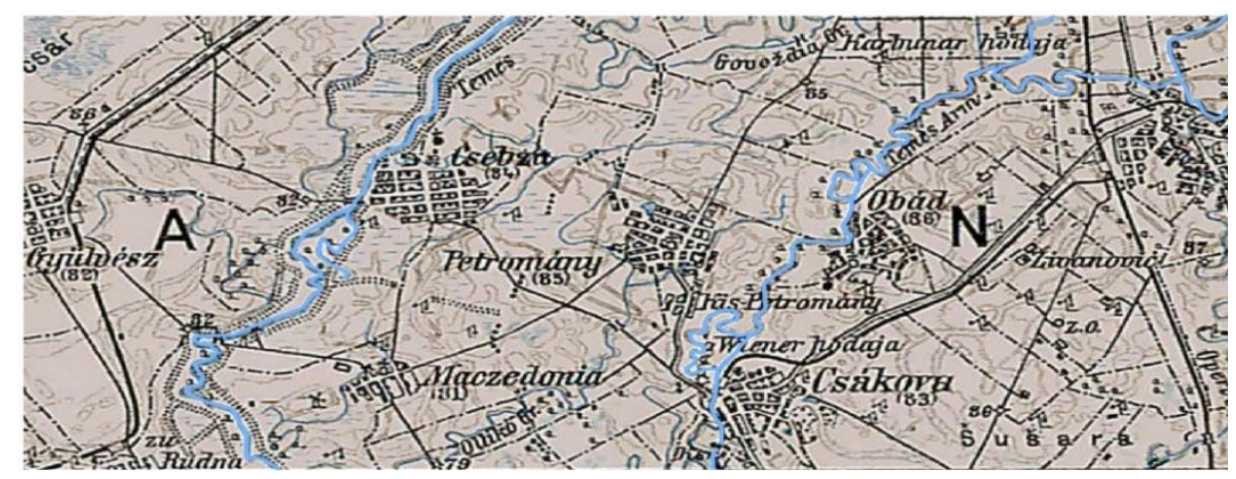

Figure 33: The third Josephine rising: Cebza - Petroman - detail.

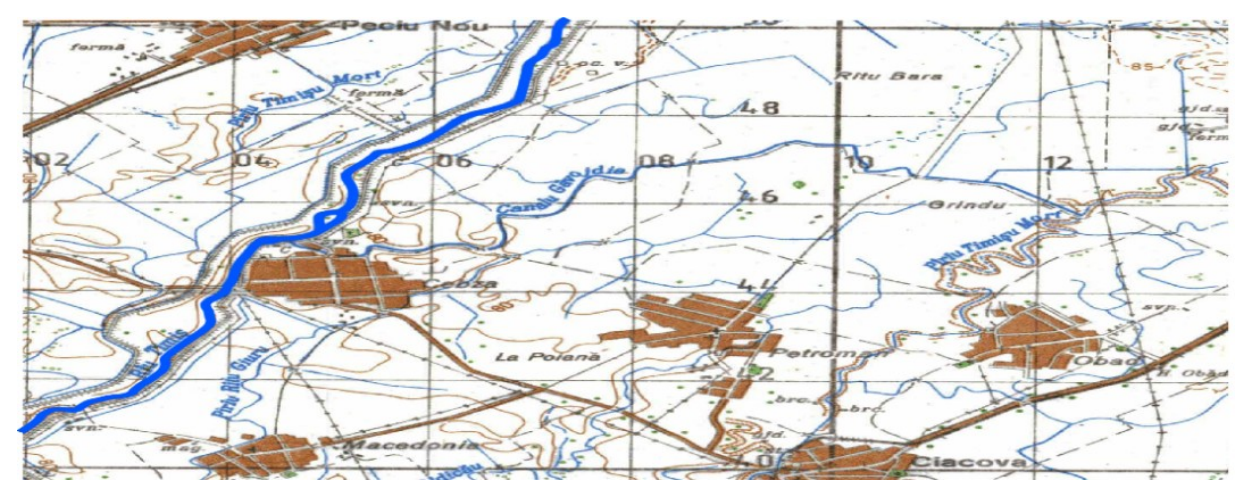

Figure 34: Kind topographic - Cebza - Petroman - detail 1996.

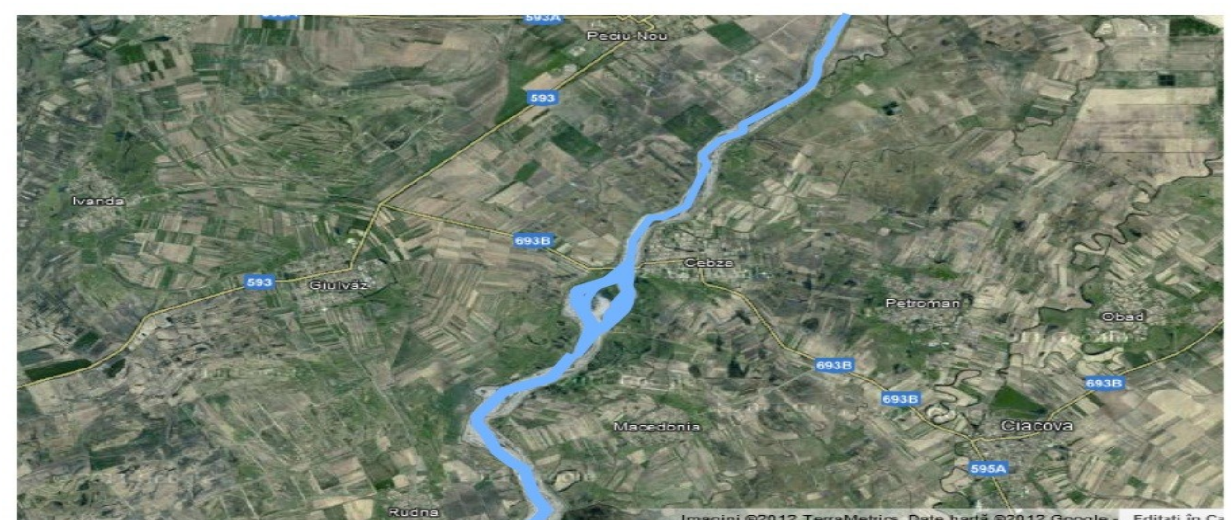

Figure 35: Satellite maps - Cebza - Petroman - detail 2012. 


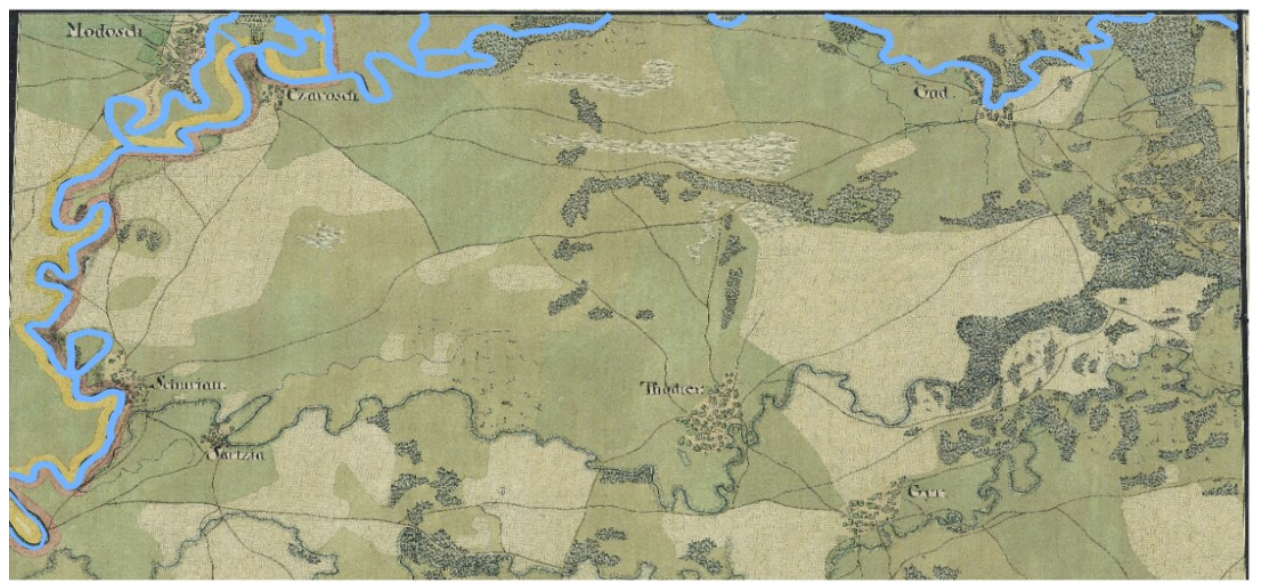

Figure 36: The first Josephine rising: Gad - Cruceni - detail.

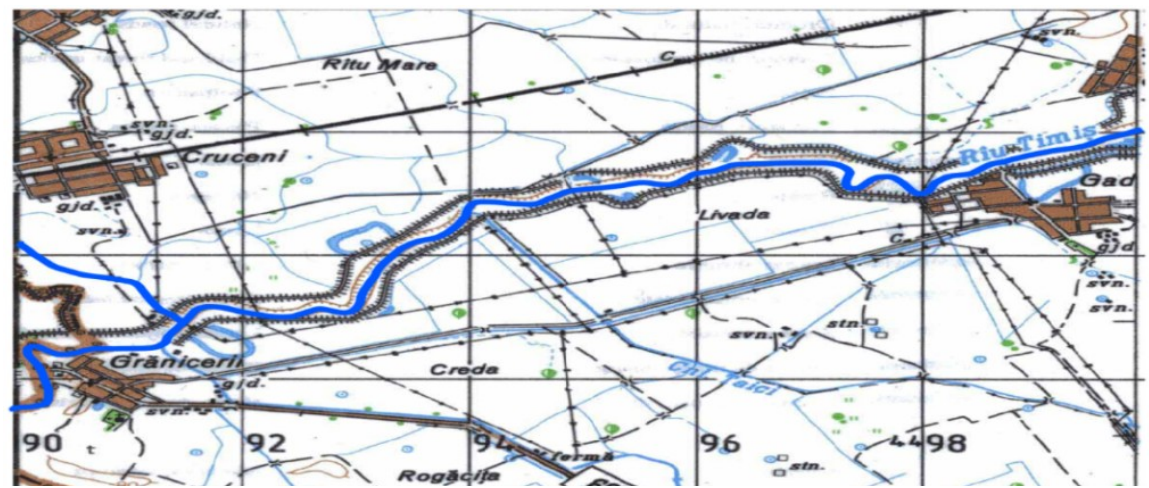

Figure 37: Kind topographic - Gad - Cruceni - detail 1996.

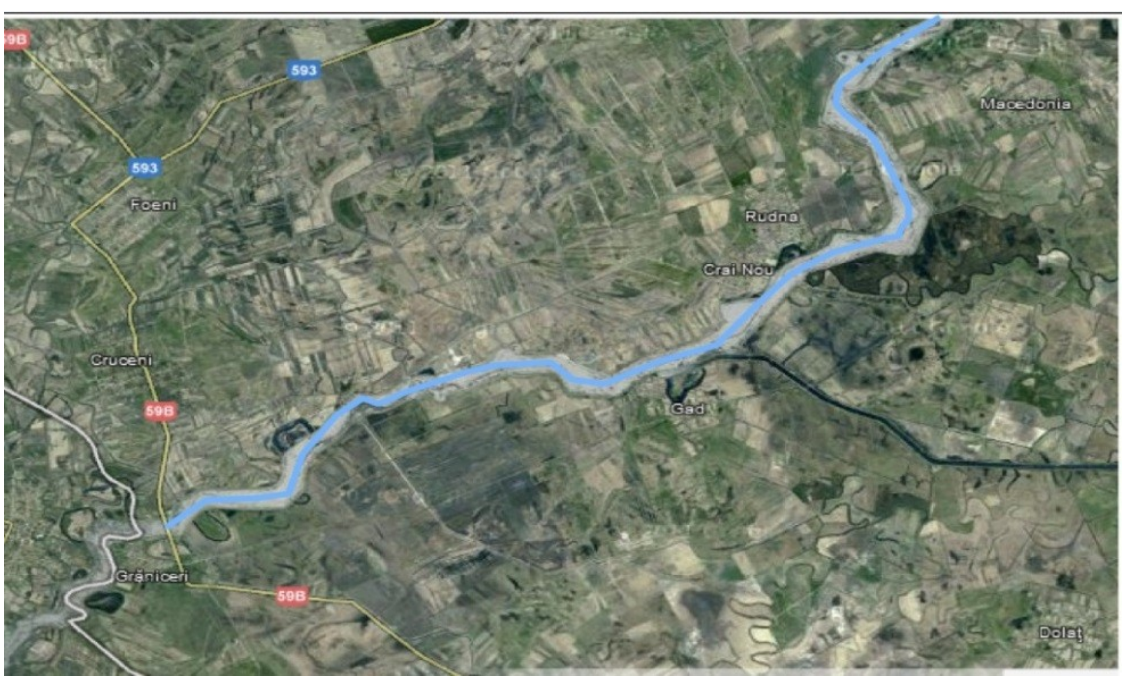

Figure 38: Satellite maps - Gad - Cruceni - detail 2012. 
At the level of the Timiş River basin there have been identified a number of anthropogenic intervention as well as hydro-technical structures, industry, intensive agriculture and human settlements which have contributed over time to alteration of morphological and ecological conditions of the water body review.

\section{Hydrotechnical structures}

The main anthropogenic interventions which have been highlighted in the Timiş River basin are hydrotechnical structures (Fig. 39), some of them old, making the hydrologic risk relatively high as a result of the low slope of the relief in these areas, high waters and floods and the surplus of water located close to surface $(*, 2010-2011)$ but also for the improvement of navigation, water demand of the towns and industrial activities and energy production.

Within the catchment area of the river Timiş there have been identified, in sectors where the risk of water is accentuated, several classes of hydro-technical works - for example special hydro-technical works, water accumulations, settlement works and construction of dikes and bank defences

Special hydro-technical works have been made in order to solve problems such as excess moisture, flood control, water supply of human settlement, and not in the least to ensure optimal flows for navigation.

This category includes a number of technical works, some historical, such as double interconnection Timiş - Bega River, Italian Channel (1860) and Semenic Channel (1911) on the body of Bârzava.

The most important hydrotechnic work is the double interconnection Timiş-Bega which was started in 1757 by building a dam on the Bega canal at Coștei town and a large ditch to Timiş River under the supervision of engineer Maximilian Fremaut. The double interconnection Timiș-Bega involved the creation of several types of channelling and water course regulations on the Timiș-Bega canal - Serbian border sector, the derivation of the Timiş River in Bega canal and vice versa, embankment, hydraulic components of derivation - Coştei (Timiş River) and Topolovăţ (Bega Canal), hydraulic components of biefare - U.H.E. Timişoara (www.rowater.ro).

Accumulation of water built for energy, water supply system and flood avoidance are located mainly on the Timis River (Trei Ape water accumulation with a total volume of 143 * $103 \mathrm{~m}^{3}$, Hitiaș accumulation and Pădureni accumulation with a volume of $35 \mathrm{mil}^{3}$ ) and some tributaries like the Lanca Birda River (Liebling accumulation with an area of 60 ha and Gad accumulation with a total volume of 20,500 mil. $\mathrm{m}^{3}$ ), Bistra Mărului River (Poiana Mărului accumulation with a capacity of $96000 * 103 \mathrm{~m}^{3}$ ), Pârâul Rece River (Poiana Ruscă accumulation with a total volume of $142 * 103 \mathrm{~m}^{3}$ ), Sucu River (Scorilo accumulation with a capacity of 25 mil. $\mathrm{m}^{3}$ ), Bârzava River and its tributaries (Secul with a total volume of $31 * 103$ $\mathrm{m}^{3}$, Văliug with a total volume of $1,200 \mathrm{mil} \mathrm{m}^{3}$, Gherteniș, Gozna with a total volume of 11,500 mil m², Fizeș, Pastoane, Valea Satului and Valea Vina Satului accumulations) Pogăniş River (Cadâr-Budoz accumulation with a total volume of 41,4 mil m³), Surugani River (Salcia accumulation with a total volume of $1,530 \mathrm{mil} . \mathrm{m}^{3}$ ), Silagiu (Sulagiu accumulation with a total volume of 0,640 mil m3), Fața River (Herendeș accumulation with a total volume of 1,600 mil $\mathrm{m}^{3}$ ), Sebeș River (Zervești accumulation with a total volume of $1,1 \mathrm{mil}^{3} \mathrm{~m}^{3}$ ) Boculandia River (Boculandia accumulation), Moravița River (Butin and Nanoviște accumulations) Semnița River (Lățunaș accumulation) and Clopodia River (Pruni accumulation) (Aldescu, 2010, Liuba, 2003; *,2008; *, 2009; *, 2010-2011; www.caransebes.ro). 
The most important reservoir of the Timiş water catchment is Trei Ape built in 1969 . This is located on the upper course of the river Timiș River, at an altitude of $835 \mathrm{~m}$, in Gărâna Depression and is fed by the water bodies Brebu, Semenic and Grădiște. The accumulation has an area of $526 * 103 \mathrm{~m}^{2}$ and a capacity of $4796 * 103 \mathrm{~m}^{3}(*, 2009)$. The lake serves the city water supply and industrial installations in Resita city and provides electricity.

Regulation and embankment works were made in sectors where hydrological risk is accentuated. According to CJ Timiș and Annex SH Banat management plan, the Timiș River basin is about $828 \mathrm{~km}$ dykes and $647.5 \mathrm{~km}$ regulation work distributed as: on Timiș River, the section between Lugoj city and border, embankment works occupies $472 \mathrm{~km}$ and regulation work have a length of 273 km; on Bârzava River, between Reșița city and border, embankment works have a length of $197 \mathrm{~km}$ and regulation work have a length of $155 \mathrm{~km}$; on Moravița River, between Moravița River and border, embankment works have a length of $50 \mathrm{~km}$ and regulation work have a length of $48 \mathrm{~km}$; on Bistra River, between Oțelu Roșu city and confluence with the river Timiș, a length of $3.0 \mathrm{~km}$ are damming and regulation works; on Pogăniş, between Apadia city and county boundary Timiş - Caraș-Severin, regulation and embankment works have approximative $63 \mathrm{~km}$ length; on Biniș River regulation work have approximative $3.8 \mathrm{~km}$; on Chizdia River downstream of the confluence with Hitiaş River, regulation work have $7.2 \mathrm{~km}$; on Timișana River the regularization of the bed have a length of $21 \mathrm{~km}$ while work impoundments have a length of $18 \mathrm{~km}$; on Faţa River regulation works extends over the entire length $(7 \mathrm{~km})$; on Lanca Birda River, the section between Voiteg and Gad are damming works a portion of $25.1 \mathrm{~km}$ on the left and $24.7 \mathrm{~km}$ on the right bank; on Vâna Mare River regulation work reach a length of $16.3 \mathrm{~km}$; on the Timișat River settlement works are executed on a length of $50.2 \mathrm{~km}$.

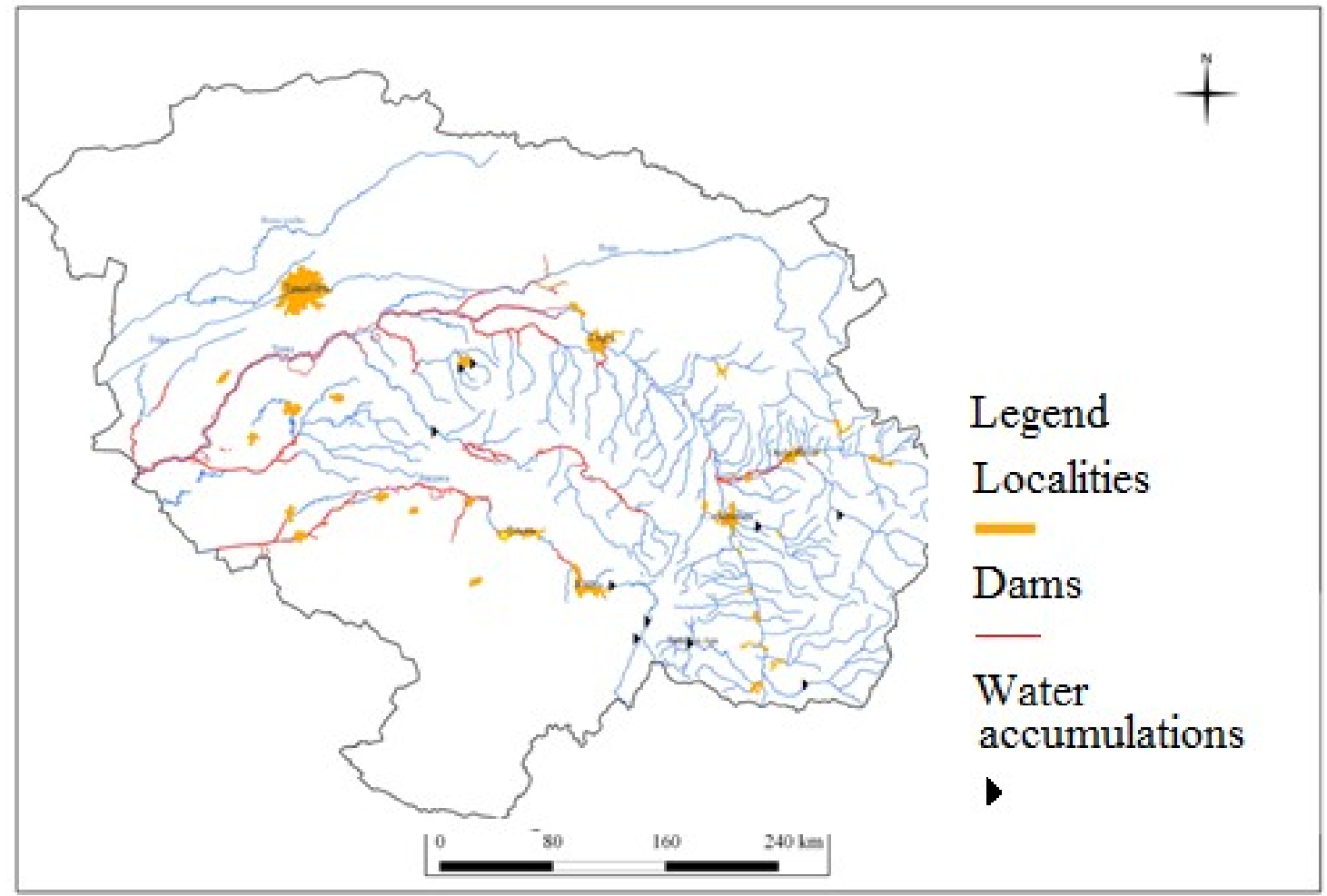

Figure 39: Hydro-technical structures. 
Human settlements are permanent sources of pollution of water and air produced by human activity, industry and transport. Domestic and industrial wastewater discharge in rivers and lakes has led to serious degradation of water quality in impaired ability to self purification and not least the removal of aquatic biota (O'Connor, 2005; Sommerwerk et al., 2009).

Construction of wastewater treatment plants has generated a major reduction in biodegradable organic matter and improved water quality but due to the fact that they are generally limited to large human settlements, a significant amount of dissolved organic matter and nutrients from smaller communities is evacuated today in lotic systems (Sommerwerk et al., 2009, Sabater et al., 2009).

To prevent the environment from the effects of the discharge of insufficiently treated municipal sewage and industrial biodegradable wastewater the Directive 91/271/EEC was created by which Member States ensure for all agglomerations, equipping with systems for the collection of urban waste water before it is discharged.

For the rehabilitation and conservation of water bodies, Romania joined and transposed the Directive 91/271/EEC into national law by H.G. 188/20.03.2002 provisions for approval of rules on the conditions for discharge into the aquatic environment of waste water treatment, as amended by Government decision 352/11.05.2005 as amended by Government decision No. 210 of 28.02.2007, which provides that human agglomerations: over 10,000 citizens shall be provided with wastewater collection systems by the end of 2013 and up to 31.12 in 2015 must provide tertiary treatment of wastewater; between 2000 - 10000 citizens shall be provided with wastewater collection system and ensure a biological treatment of wastewater by 31.12 .2018 .

In view of the obligations and time commitments of the Romanian state through the Treaty of Accession, most settlements of the 69 administrative units existing in the basin of the Timiş River must conform to new provisions on the collection and the treatment of discharged wastewater in an emissary.

In 2012, the collection of wastewater took place in 29 municipalities while the mechanical and biological treatment activity wastewater was done in only 16 .

The degree of adaptation of administrative units to collection systems and wastewater treatment depends on the number of people equivalent is shown in table number 1, and figures number 40 and 41 .

Table 1: The relationship between wastewater collection and treatment.

\begin{tabular}{|l|c|c|c|c|}
\hline \multirow{2}{*}{$\begin{array}{c}\text { Administrative } \\
\text { units (a.u.) }\end{array}$} & $\begin{array}{c}\text { The number of } \\
\text { a.u. within the } \\
\text { basin }\end{array}$ & $\begin{array}{c}\text { Systems for the collection of waste } \\
\text { water }\end{array}$ & $\begin{array}{c}\text { Wastewater } \\
\text { treatment }\end{array}$ \\
\cline { 3 - 5 } & & $\begin{array}{c}\text { No. of a.u. } \\
\text { connected to } \\
\text { wastewater } \\
\text { collection systems }\end{array}$ & $\begin{array}{c}\text { The degree of } \\
\text { connection to } \\
\text { the sewer a.u. }\end{array}$ & $\begin{array}{c}\text { No. of a.u. } \\
\text { connected to a } \\
\text { wastewater } \\
\text { treatment } \\
\text { systems }\end{array}$ \\
\hline$>10000$ 1.e. & 5 & 5 & $35 \%-71 \%$ & 4 \\
\hline 2000 1.e. & 39 & 15 & $14 \%-94 \%$ & 10 \\
-10000 l.e. & 25 & 2 & $20 \%$ and $80 \%$ & 2 \\
\hline$<2000$ l.e. & & & & \\
\hline
\end{tabular}




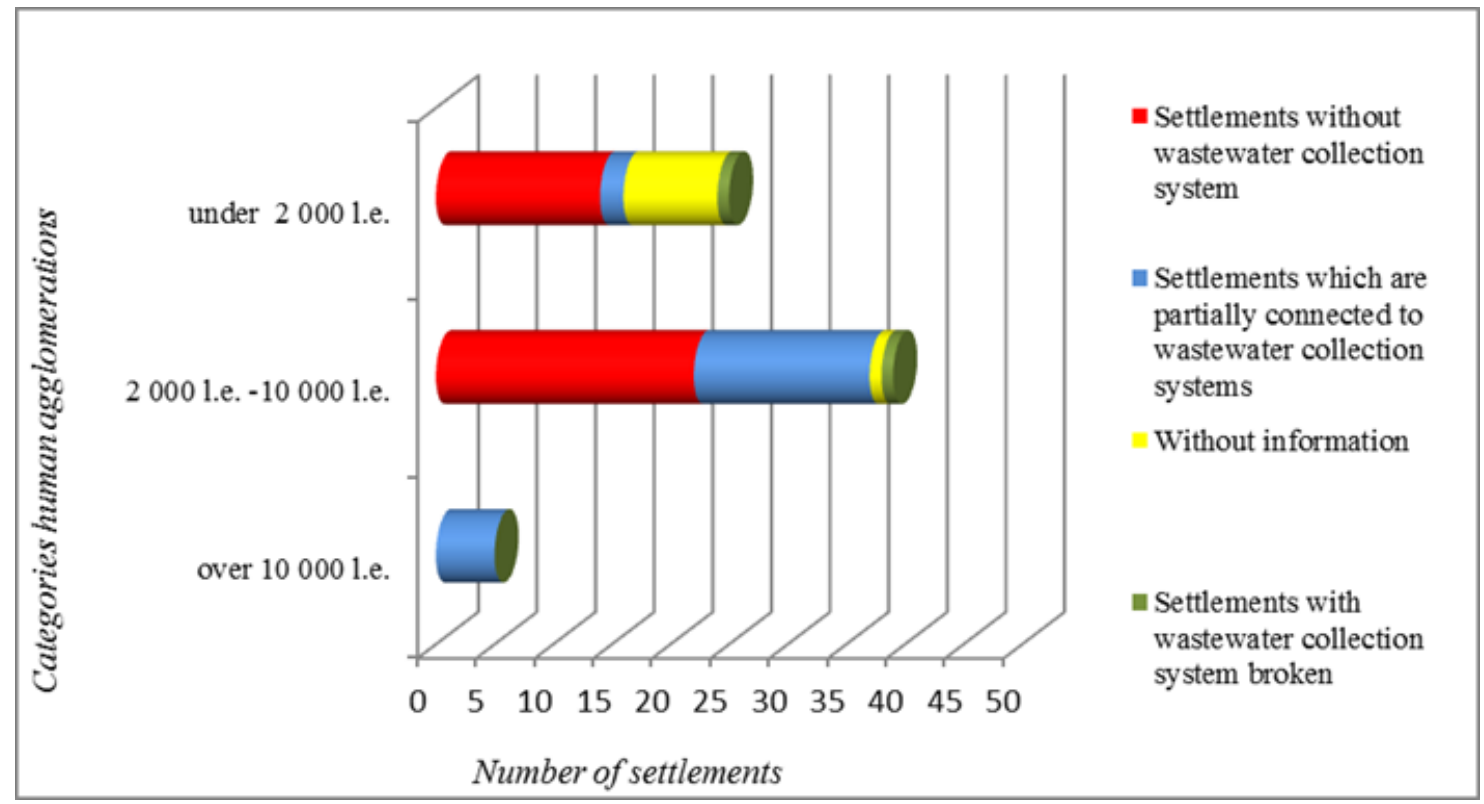

Figure 40: Situation degree of connection to wastewater collection systems.

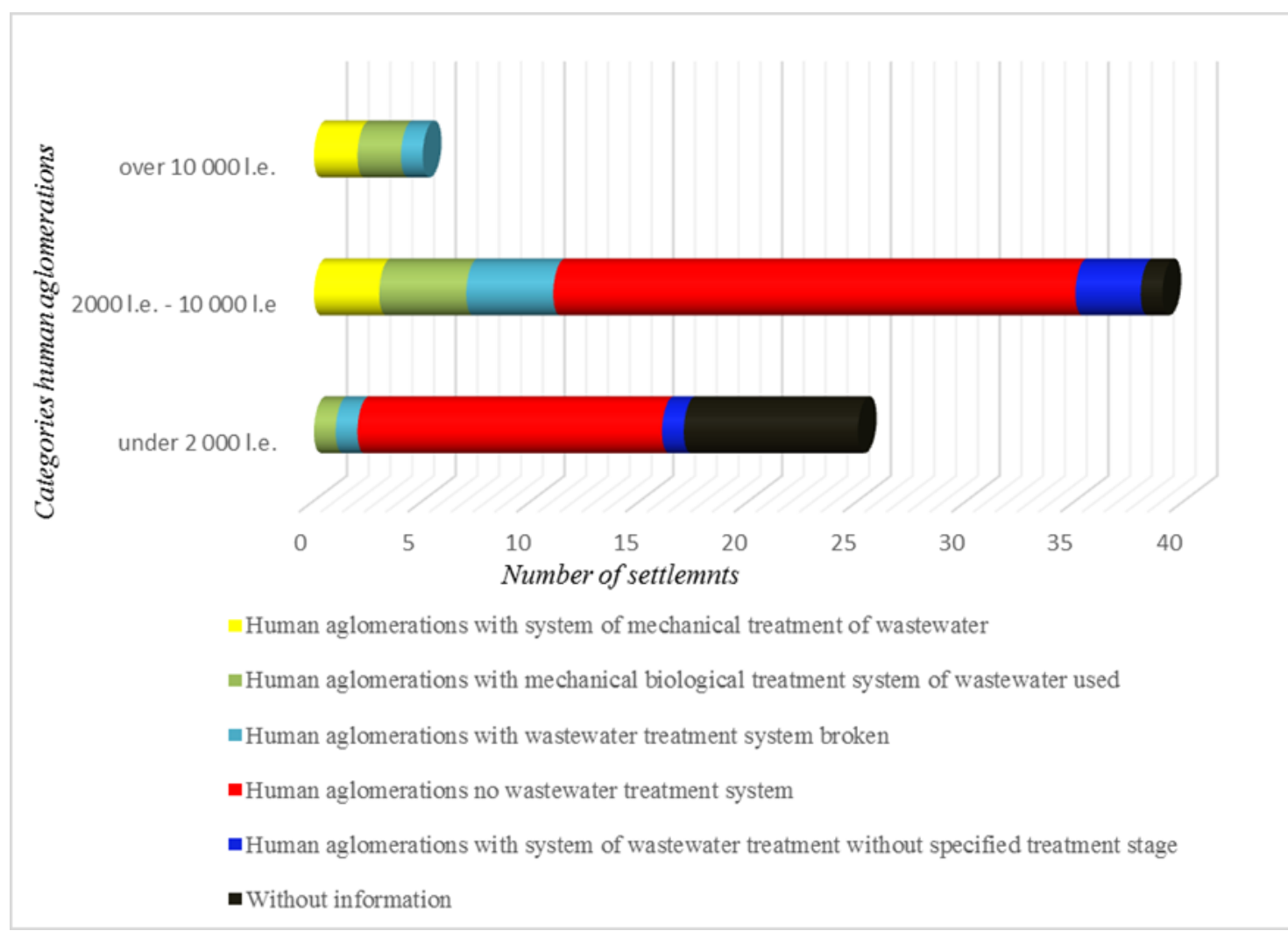

Figure 41: Situation degree of connection to wastewater treatment systems. 
At that time most of the administrative units are beginning efforts to obtain financing for the construction and or extension of sewerage and waste water generated, but a large part failed to obtain the necessary financing.

In view of the above, to reduce human agglomeration pressures it is necessary to rehabilitate and/or upgrade existing sewerage and treatment; construction and/or expansion of these systems in all urban agglomerations in the basin including in that number is less than 2000 population equivalent.

\section{Main economic activities in the basin of the Timiş River}

In the hydrographic basin of the Timiş River, the quality of surface and groundwater is directly influenced by economic activity. The most significant changes in the state of water quality are mainly generated by industrial and agricultural units whose activity results in wastewater loaded with a number of organic compounds and chemicals.

Regarding the industrial activity in the studied area, this is characterized by a great diversity of activities. The main industrial sectors represented in Caraş-Severin County are mining, metallurgy and machine building industry while in the Timiș County a large share is held by the processing industry with its main branches: food industry, chemical industry, metal and wood processing industry (www.adrvest.ro).

As a result of the registry of pollutants from the Timiş River basin, the main economic activities that may be potential sources of pollution are presented in table number 2 .

Table 2: Register of pollutants in the water catchment area of the river Timiș (20112012); Research contract PHARE CBC "Protective Measures for Timiş River"; SH banned Annexes management plan; www. rowater.ro; www.firme.info.

\begin{tabular}{|c|c|c|c|}
\hline $\begin{array}{l}\text { Crt. } \\
\text { no. }\end{array}$ & $\begin{array}{l}\text { Activity } \\
\text { domain }\end{array}$ & $\begin{array}{l}\text { Industry } \\
\text { sector }\end{array}$ & $\begin{array}{c}\text { No. of } \\
\text { ind. units }\end{array}$ \\
\hline \multirow{18}{*}{1.} & \multirow{18}{*}{$\begin{array}{l}\text { Processing } \\
\text { industry }\end{array}$} & Food industry & 17 \\
\hline & & Manufacture of beverages & 3 \\
\hline & & Leather industry & 10 \\
\hline & & Wood processing industry & 21 \\
\hline & & Manufacture of wood, cork, straw and plaiting products & 12 \\
\hline & & Manufacture of paper and paper products & 6 \\
\hline & & Manufacture of chemicals and chemical products & 6 \\
\hline & & Manufacture and preparations of basic pharmaceuticals & 1 \\
\hline & & Manufacture of rubber and plastic & 23 \\
\hline & & Manufacture of other non-metallic mineral products & 29 \\
\hline & & Metallurgical industry & 4 \\
\hline & & Metallic construction and products, except machineries & 24 \\
\hline & & Manufacture of electrical equipment & 3 \\
\hline & & Manufacture of machinery and equipment & 13 \\
\hline & & Manufacture of motor vehicles, trailers and semi-trailers & 8 \\
\hline & & Manufacture of furniture & 30 \\
\hline & & Other manufacturing n.c.a. & 1 \\
\hline & & Repair and installation of machinery and equipment & 2 \\
\hline
\end{tabular}


Table 2 (continuing): Register of pollutants in the water catchment area of the river Timiș (2011-2012).

\begin{tabular}{|c|c|c|c|}
\hline $\begin{array}{l}\text { Crt. } \\
\text { no. }\end{array}$ & $\begin{array}{l}\text { Activity } \\
\text { domain }\end{array}$ & $\begin{array}{c}\text { Industry } \\
\text { sector }\end{array}$ & $\begin{array}{l}\text { No. of } \\
\text { ind. units }\end{array}$ \\
\hline 2. & $\begin{array}{l}\text { Electricity, } \\
\text { gas, steam } \\
\text { and air } \\
\text { conditioning } \\
\text { production } \\
\text { and supply }\end{array}$ & $\begin{array}{l}\text { Production and supply of electricity, gas, steam and air } \\
\text { conditioning }\end{array}$ & 2 \\
\hline \multirow[t]{2}{*}{3.} & \multirow{2}{*}{$\begin{array}{l}\text { Water } \\
\text { supply, } \\
\text { sewerage, } \\
\text { waste } \\
\text { management } \\
\text { and } \\
\text { remediation } \\
\text { activities }\end{array}$} & Collection, purification and distribution of water & 6 \\
\hline & & $\begin{array}{l}\text { Collection, treatment and disposal; materials recovery } \\
\text { activities }\end{array}$ & 27 \\
\hline 4. & Construction & Civil engineering and specialized construction & 5 \\
\hline 5. & $\begin{array}{c}\text { Civil } \\
\text { engineering } \\
\text { and } \\
\text { specialized } \\
\text { construction }\end{array}$ & $\begin{array}{l}\text { Wholesale and retail trade and repair of motor } \\
\text { vehicles and motorcycles; } \\
\text { Wholesale except of motor vehicles and motorcycles; } \\
\text { Retail trade, except of motor vehicles and motorcycles. }\end{array}$ & 100 \\
\hline 6. & $\begin{array}{l}\text { Transport } \\
\text { and storage }\end{array}$ & $\begin{array}{l}\text { Land and by pipes transport; } \\
\text { Warehousing and support activities for transportation; }\end{array}$ & 11 \\
\hline 7. & Mining & Gravel pits. & 19 \\
\hline
\end{tabular}

The wastewater from these activities is discharged into the municipal sewer system or directly into a natural emissary. Making a correlation with the situation of wastewater collection and systems of wastewater treatment in the river basin, we can conclude that the domestic and industrial wastewater generated in the Timiș River basin is not sufficiently purified.

The absence or insufficient residual wastewater treatment leads to pollution of surface water with organic substances and with chemical substances. Pollution by organic substances produces a significant impact on aquatic ecosystems by changing species composition, decreasing the biodiversity in species and reducing the fish population or increasing fish mortality in the context of the drastic reduction of oxygen. Pollution by dangerous substances (synthetic pollutants and/or synthetic pollutants) produces toxicity, persistence and bioaccumulation in the aquatic environment $(*, 2013)$.

\section{Agricultural activity}

Along with the industry, agriculture could become one of the major sources of pollutants with negative impact on the quality of the environment through environmental degradation or even the destruction of ecosystems. Nowadays it is almost universally accepted that intensive farming can lead to pollution of soil and water through excessive use of 
fertilizers, pesticides, improper irrigation water quality and quantity, and arable land excessively loose through various works. Polluting agents such as toxic substances can accumulate in quantities exceeding the maximum allowable limits in both surface waters and groundwater. $(*, 2005)$.

Improper agricultural practices associated with irrigation and drainage, that may incorrectly add a disconnection of the management and use of agricultural land and irrational use of forestry, determine the rise and intensified physical degradation of the soil, through processes like deconstruction, compacting, crusting, wind and water erosion, overexploitation of groundwater, alteration of natural habitats, contributing even more to increased pollution in different ways to the main components of the environment. (O'Connor, 2005; *, 2006).

Large inputs of different compounds from agriculture have led to unexpected and very serious side effects in aquatic ecosystems, such as mass mortality of organisms, challenge of mutations and cancer diseases in humans and animals, reducing primary production process, accumulation in the food chain rings, high toxicity, and last but not least a tolerance induced (Barbu, 2010; *, 2005).

Major sources of agricultural pollution in the basin are represented by the ranches distributed mostly in the Timiş River floodplain area that according to the Registry of Protected Areas Banat is an area sensitive to nitrates.

The main agricultural units identified in the basin are the pig breeding farm, poultry farms, the sheep and goat farms, dairy farms and mixed activities farms. Their spatial distribution in the basin is shown in figure number 41.

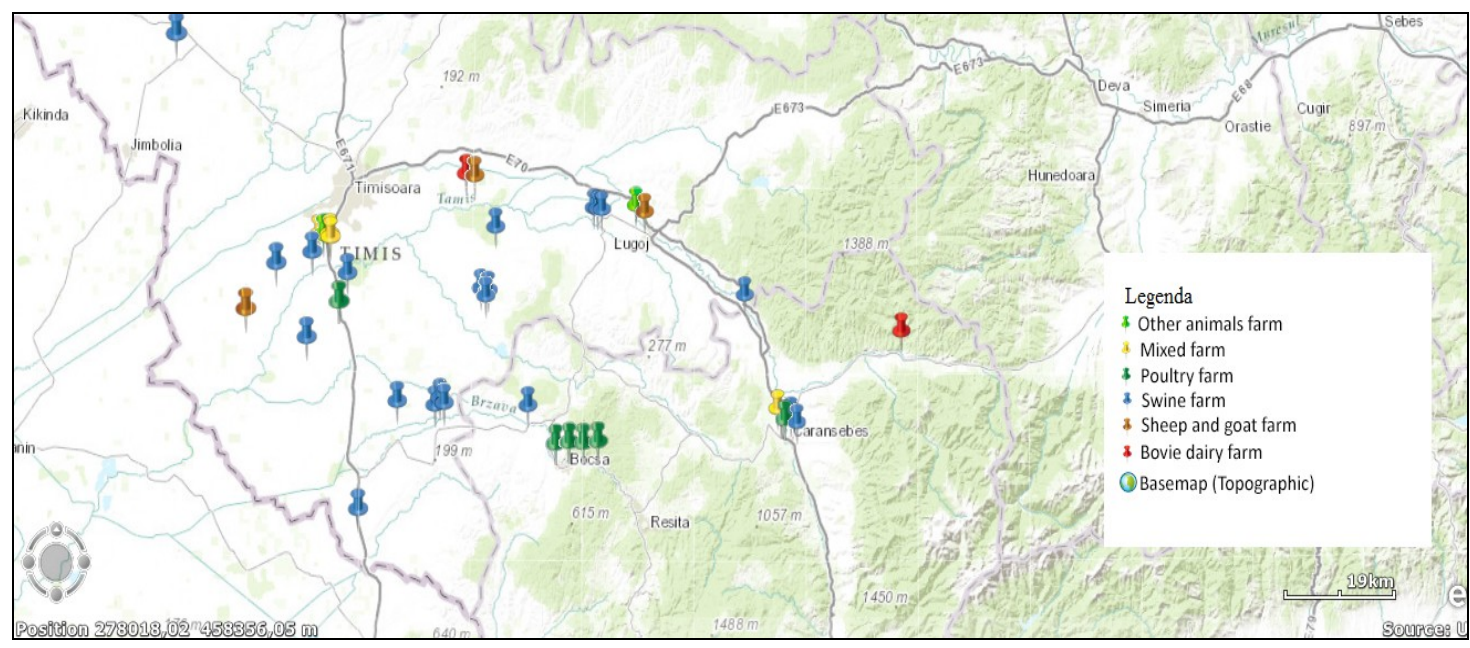

Figure 41: Spatial distribution of the main farms in the basin of the river Timiş, 2012.

Agricultural development in floodplains along the river regulation works made for different economic purposes (shipping, embankment works, and water accumulation) led to the loss of wetlands (approximative 50\%) and flood plains (95\%) (Tockner et al., 2009).

In Timiş River basin, such situations are encountered mainly in the middle of the river Timiş, specifically on the Caransebeş - Cruceni. The result of such operations is loss of arms, meanders cutting, river bed straightening, and disappearance of wetlands that used to characterize Timiş River (Fig. 2). 


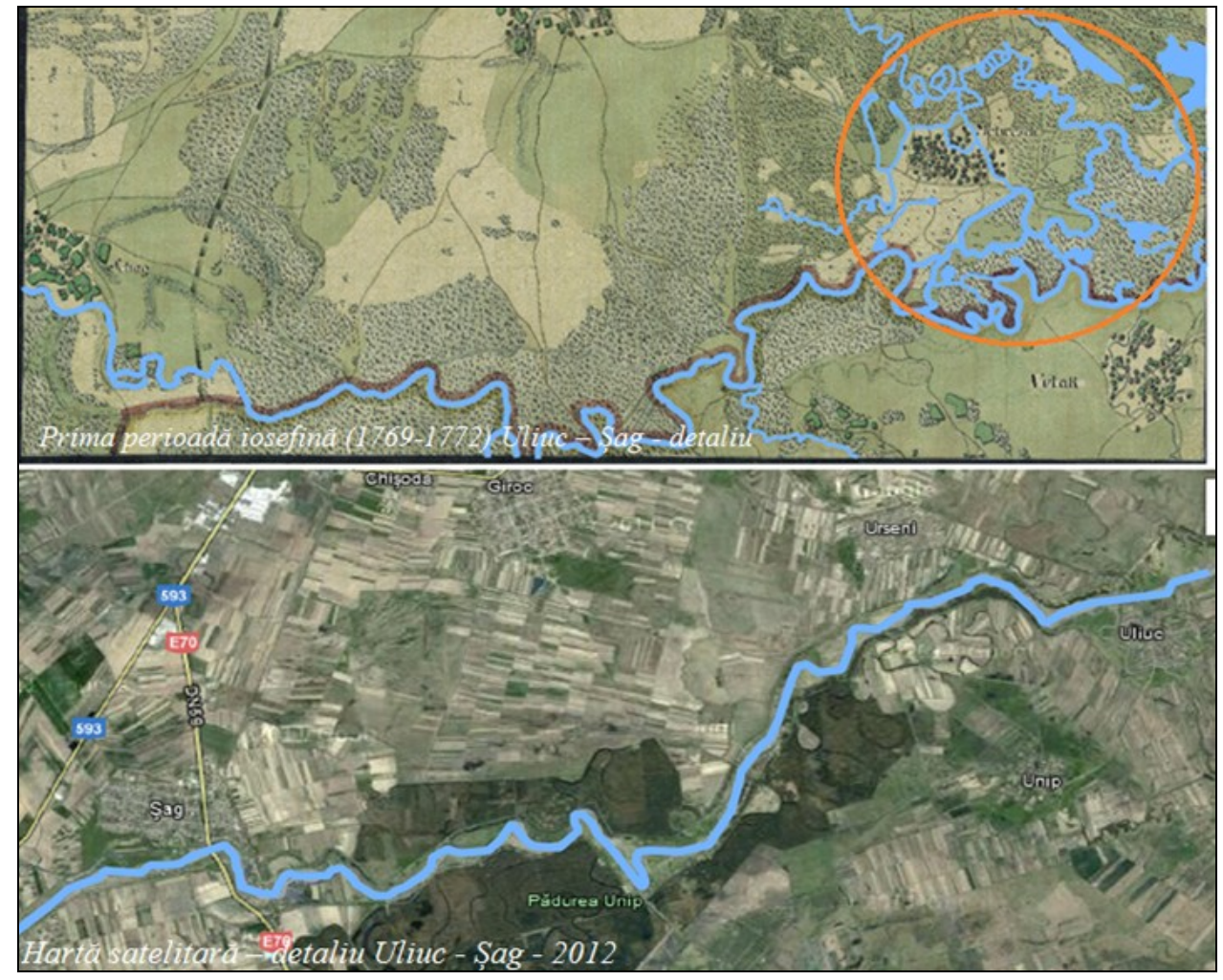

Figure 42: Changes in the Timiș River - detail Uliuc - Şag.

\section{CONCLUSIONS}

The main human pressures that have a negative impact on the Timiş River basin are hydraulic works (special hydro-technical works, water accumulations, settlement works and construction of dikes and banks defence), agricultural and industrial development, and urbanization.

In order to achieve the objectives of the Water Framework Directive it is necessary to implement management measures for the entire basin, so it is recommended to consider the following:

- in terms of hydraulic works: it should be established the ecological flow downstream of works and it should be studied their potential impact; regulating the transfer of water from one reservoir to another so none of the reservoirs should be under or over the optimal volume;

- to reduce pressure from agricultural and industrial development is recommended to reduce discharges of industrial wastewater in sewers, especially those from metallurgy, pharmaceutical and chemical;

- to reduce agglomeration pressure rehabilitation and/or modernization of sewage and waste systems is recommended; construction and/or expansion of wastewater treatment plants and collection systems, including agglomerations where the number of inhabitants is below 2000 , i.e. waters discharged into the environment to be within legal required quality;

- development of a waste collection system from both household and economic activity, so waste will not be stored on the river's banks; also it is recommended to inform the population about the importance of selective collection and to provide the necessary infrastructure for selective collection. 


\section{ACKNOWLEDGMENTS}

This paper results are based on the scientific field campaigns of the project "Study of the quality of Timiş water and registry of polluters source to border" (IV.1.2), a Phare CBS project, no. 411, - 90964/30.12.2010/07, of "Lucian Blaga" University, Faculty of Sciences, financed by the European Community. 


\section{REFERENCES}

1. Alcamo J., Flörke M. and Märkle M., 2007 - Future long-term changes in global water resources driven by socio-economic and climatic changes, Hydrological Sciences Journal Journal des Sciences Hydrologiques, 52, 247-275.

2. Aldescu V. C., 2010 - Studiul inundațiilor pe Râul Timiş amenajat în conceptul „mai mult spațiu pentru râuri” Lucrare de doctorat, Universitatea „Politehnica” din Timișoara, 150152. (in Romanian)

3. Allan J. D., 2004 - Influence of land use and landscape setting on the ecological; status of rivers, Limnetica, 23, 187-198.

4. $\quad$ Antonescu S., Balintoni P., Balu I., Bârsescu A., Boldea V., Cătană N., Crișan I., Cristescu I., Deleanu M., Doclin O., Fried E., Galescu C., Hillinger N., Iordăchescu F., Jurjica T., Jurma G., Mănăilă N., Munteanu,V., Naidan I., Oallde P., Odărescu I., Olaru M., Popa I., Poterașu M., Răuț O., Rădăuț C., Reichenbach P., Sârbu N., Serban I., Tudor M., Țeicu S., Urseanu A., Uzum I., Vânătoru M., Vulpeș N. and Zeberca V., 1981 - Caraş-Severin - Monografie, Edit. Sport-Turism, București. (in Romanian)

5. Badea L., Bogdan O., Bugă B., Cucu V., Donisă I., Gâștescu P., Ianovici V., Iordan I., Niculescu G., Oancea D., Posea G., Savu A., Sencu V., Velcea and Velcea, 1992 - Geografia României IV. Regiunile Pericarpatice: Dealurile și Câmpia Banatului şi Crișanei, Podişul Mehedinți, Subcarpații, Piemontul Getic, Podișul Moldovei, Edit. Academiei Române, București. (in Romanian)

6. Barbu C. H., 2010 - Factori chimici de risc ecologic. Suport de curs pentru uzul studenţilor, Universitatea "Lucian Blaga" din Sibiu - Catedra de Ecologie şi Protectia Mediului. (in Romanian)

7. Bradea M., Iordache M., Morodan I., Minda L. and Bălan R., 1981 - Timiș monografie, Edit. Sport-Turism, București, 11. (in Romanian)

8. Curtean-Bănăduc A., 2005 - Râul Cibin, caracterizare ecologică, ISBN 973-739-195-0, 240. (in Romanian)

9. Curtean-Bănăduc A., Bănăduc D. and Sîrbu I., 2005 - Transylvanian Review of Systematical and Ecological Research, 2, The Târnava River Basin, 182.

10. Curtean-Bănăduc A., Bănăduc D. and Sîrbu I., 2011 - Transylvanian Review of Systematical and Ecological Research 11, The Upper Tisa River Basin, 204.

12. Diamond J., 2011 - Collapse: How Societies Choose to fail or Succeed: Revised Edition, Penguin Books, ISBN-10: 0143117009, 608.

13. Olteanu, F. 2004 - Toponimele şi hidronimele de origine nelatină în lucrările de antiquis et hodiernis moldaviae nominibus şi historia moldo-vlachica de Dimitrie Cantemir. Ovidius University Annals of Philology Volume XV, Number 143-152, 2004, 14, (http://litere.univovidius.ro/Anale/04\%20volumul\%20XV\%202004/15\%20Florentina\%20Oltea nu.pdf). (in Romanian)

14. Goubert J.-P., 1989 - The Conquest of Water: The Advent of Health in the Industrial Age. Princeton.

15. Griselini F. and Feneşan C. 1984 - Încercare de istorie politică şi naturală a Banatului Timişoarei, Edit. Facla Timişoarei, 22-234. (in Romanian)

16. Hughes J. D. (ed.), 1978 - An Environmental History of the World, Routledge, London.

17. ICPDR, 2004 - International Commission for the Protection of the Danube River (ICPDR) 2004, Danube Basin Analysis (WFD Roof report 2004). ICPDR Document IC/084, 18 March 2005, Vienna, Austria. http://www.icpdr.org/icpdr-pages/reports.htm.

18. Curtean-Bănăduc A., Bănăduc D. and Sîrbu I., 2011 - Transylvanian Review of Systematical and Ecological Research, 11, The Upper Tisa River Basin, 204

19. ICPDR, 2006 - International Commission for the Protection of the Danube River (ICPDR). 2006. Convention on Co-operation for the Protection and Sustainable Use of the River Danube. 15 March 2006. Vienna, Austria. http://www.icpdr.org/icpdr-pages/drpc.htm 
20. Lacoste Y., 2003 - Apa bătălia pentru viață, Enciclopedia Rao, București. (in Romanian)

21. Litvinov A. S., Mineeva N. M., Papchenkov V. G., Korneva L. G., Lazareva V. I., Shcherbina Grigory K., Gerasimov Y. V.; Dvinskikh S. A., Noskov V. M., Kitaev A. B., Alexevnina M. S., Presnova E. V., Seletkova E. B., Zinovíev E. A., Baklanov M. A., Okhapkin A. G. and Shurganova G. V., 2009 - Volga River Basin, in Tockner K., Uehlinger U. and Robinson C. T. (eds), Rivers of Europe, Elsevier Ltd., USA.

22. Liuba C., 2003 - Che Ruieni-Furnizor de servicii tehnologice pentru SEN (http://www.et.upt.ro/cee/ro/psc/works03/psc49.pdf). (in Romanian)

23. Malmqvist B. and Rundle S., 2002 - Threats to the running water ecosystems of the world, Environmental Conservation, 29, 134-153.

24. Mândruț O. 1993 - Geografia României ( geografie generală și regională), Edit. Coresi, București. (in Romanian)

25. Müller N., 1995 - River dynamics and floodplain vegetation and their alterations due to human impact, in Lampe W. (ed.), Archiv Für Hydrobiologie, E. Schweizerbart'sche Verlagsbuchhandlung (Nägele U. Obermiller), Stuttgart.

26. Munteanu I. and Munteanu R., 1998 - Timiș monografie, Edit. Marineasa, Timișoara.

27. O’Connor P. J., 2005 - Human impacts, in Salminen R. (Chief-editor), Batista M. J., Bidovec M., Demetriades A., De Vivo B., De Vos W., Duris M., Gilucis A., Gregorauskiene V., Halamic J., Heitzmann P., Lima A., Jordan G., Klaver G., Klein P., Lis J., Locutura J., Marsina K., Mazreku A., O’Connor P. J., Olsson S. Å., Ottesen R. T., Petersell V., Plant J. A., Reeder S., Salpeteur I., Sandström H., Siewers U., Steenfelt A. and Tarvainen T., FOREGS Geochemical Atlas of Europe, Part 1: Background Information, Methodology and Maps, Geological Survey of Finland, Espoo, 63-66.

28. ICPDR, 2006 - International Commission for the Protection of the Danube River (ICPDR), Convention on Co-operation for the Protection and Sustainable Use of the River Danube, 15 March 2006, Vienna, Austria, http://www.icpdr.org/icpdr-pages/drpc.htm

29. Pandi G., 2002 - Riscul în activitatea de apărae împotriva inundaţiilor, Riscuri şi catastrofe, 2, Edit. Casa Cărţii de Ştiinţă, Cluj Napoca, 132, (http://riscurisicatastrofe.reviste.ubbcluj.ro/ Volume/I_2002/PDF/Pandi.pdf) (in Romanian)

30. Pop G., 2002 - Carpații și subcarpații României, Edit. Presa Universitară Clujeană, ClujNapoca. (in Romanian)

31. Posea G., 2002 - Geomorfologia României. Relief- Tipuri, Geneză, Evoluție, Regionare, Edit. Fundației România De Mâine, București. (in Romanian)

32. Postel S. L, 2000 - Entering an era of water scarcity: The challendes ahead, Ecological Applications, 941-948, USA.

33. Roșu A., 1973 - Geografia Fizică a României, Edit. Didactică şi Pedagogică, București. (in Romanian)

34. Sabater S., João F., Maria G., Manuel A. S., Munõz I. and Romaní A. M., 2009 - The Iberian Rivers, in Tockne, Klement U., Urs R. and Christopher T. (eds), Rivers of Europe, Elsevier Ltd., USA

35. Schuyt K., 2005 - Freshwater and Poverty Reduction: Serving People, Saving Nature: An economic analysis of the livelihood impacts of freshwater conservation initiatives, WWF International: Gland Switzerland.

36. Solomon S., 2010 - Water: The Epic Struggle for Wealth, Power, and Civilization, ISBN 10: $0060548304,608$.

37. Sommerwerk N.; Hein T., Schneider-Jacoby M., Baumgartner C., Ostojić A., Paunović M., Bloesch J., Siber R. and Tockner K., 2009 - The Danube Rivr Basin, in Tockner K., Uehlinger U., Robinson C. T. (eds), Rivers of Europe, Elsevier Ltd., USA.

38. Teodorescu N. I., 2008 - The minimum flow in the upstream basin of the Timiş River, XIVth Conference of the Danubian Countries, IOP Publishing. 
39. Tockner K., Uehlinger U. and Robinson C. T. (eds.), 2009 - Rivers of Europe, First edition, Academic Press Elsevier, ISBN-13, 978-0-12-369449-2, 728.

40. Turner W. R., Brandon K., Thomas M., Constanza R., Da Fonseca G. A. B. and Portela R., 2007 - Global Conservation of Biodiversity and Ecosystem Services, BioScience, 57, 10.

41. Ujvári I., 1972 - Geografia apelor României. Editura Științifică, București. (in Romanian)

42. *, 2002 - H.G. 188/20.03.2002 provisions for approval of rules on the conditions for discharge into the aquatic environment of waste water treatment, as amended by Government decision 352/11.05.2005 as amended by Government decision No. 210 of 28.02.2007.

43. *, 1971 - Râurile României. Monografie hidrologică, Edit. INMH, Bucureşti. (in Romanian)

44. Soroceac M., 2005- Climatic regionalization between yesterday and tommorow. Study case: The Banat plain, Romanian rewiew of regional of regional studies, I, 1.

45. Teodorescu N. I., 2008 - The minimum flow in the upstream basin of the Timis river, XIVth Conference of the Danubian Countries, IOP Publishing.

46. *, 2005 - ORDIN Nr. 1182 din 22.11. 2005 privind aprobarea Codului de bune practici agricole pentru protecţia apelor împotriva poluării cu nitraţi din surse agricole (http://www.mmediu.ro/legislatie/acte_normative/gospodarirea_apelor/Cod_Bune_Practici_Agr icole.pdf). (in Romanian)

47. *, 2006 - Mediul și Agricultura. Principii și practici privind reducerea poluării apelor cu nitrați proveniți din agricultură (http://alma-ro.ngo.ro/doc/brosuraREC.pdf). (in Romanian)

48. *, 2010-2011 - Contract de cercetare încheiat cu primăria Caransebeș în cadru proiectului PHARE CBC "Protective measures for Timiş River" financed by the European Community, 411/90964/2010-2011. (in Romanian)

49. *, 2013 - Actualizare Plan de Amenajare a Teritoriului Județului Timiș. Etapa II, II, Cadrul Natural, Mediu, Zone de Risc; Beneficiar Consiliul Județean Timiș. (in Romanian)

50. Anexa planului de management SH Banat. (in Romanian)

51. geo-spatial.org, 1

52. www.caransebes.ro

53. www.cjTimiş.ro

54. www.firme.ro

55. *, 2006 - Mediul și Agricultura. Principii și practici privind reducerea poluării apelor cu nitraţi proveniţi din agricultură (http://alma-ro.ngo.ro/doc/brosuraREC.pdf). (in Romanian)

56. *, 2013 - Actualizare Plan de Amenajare a Teritoriului Județului Timiș. Etapa II, Vol II: Cadrul Natural, Mediu, Zone de Risc; Beneficiar Consiliul Județean Timiș. (in Romanian)

57. * 2008 - Lista actualizată a micilor acumulări din categoriile de importanta C şi D, care intră sub incidenta OUG 138/2005, şi aprobată prin Legea 13/2006 , din S.H. BANAT reactualizare martie 2008, (www.mmediu.ro) (in Romanian)

58. *, 2005 - ORDIN Nr. 1182 din 22.11. 2005 privind aprobarea Codului de bune practici agricole pentru protecţia apelor împotriva poluării cu nitraţi din surse agricole (http://www.mmediu.ro/legislatie/acte_normative/gospodarirea_apelor/Cod_Bune_Practici_Agr icole.pdf). (in Romanian) 